PONTIFÍCIA UNIVERSIDADE CATÓLICA DO RIO DE JANEIRO

\title{
Análise da Viabilidade Econômico-Financeira para um empreendimento participante do Programa Minha Casa Minha Vida
}

\section{Carolina Ozenda da Costa}

RELATÓRIO FINAL DE ESTÁGIO SUPERVISIONADO II

Centro de Ciências Sociais - CCS

DePARTAMENTO de AdMINISTRAÇÃo

Curso de Graduação em Administração 
Carolina Ozenda da Costa

\section{Análise da Viabilidade Econômico-Financeira para um empreendimento participante do Programa Minha Casa Minha Vida}

Relatório Final de Estágio Supervisionado II

Relatório Final da disciplina Estágio Supervisionado II, apresentada ao programa de graduação em Administração da PUC-Rio como requisito parcial para a obtenção do titulo de Bacharel em Administração. 


\section{Agradecimentos}

Ao meu orientador, Rafael Igrejas, pelo suporte e paciência durante essa trajetória. 


\section{Resumo}

Ozenda, Carolina. Igrejas, Rafael. Análise da Viabilidade EconômicoFinanceira para um empreendimento participante do Programa Minha Casa Minha Vida. Rio de Janeiro, 2015. 54 páginas. Relatório Final de Estágio Supervisionado II - Departamento de Administração. Pontifícia Universidade Católica do Rio de Janeiro.

O setor da construção civil é relevante para o crescimento do Brasil, pois é considerado um importante gerador de empregos e desenvolvimento habitacional do país. Buscando reduzir o déficit habitacional, o governo passou a disponibilizar recursos para estimular o mercado imobiliário brasileiro através do Programa Minha Casa, Minha Vida, possibilitando o acesso das famílias de baixa renda a adquirir moradias.

Dessa maneira, faz-se necessário realizar uma análise econômicofinanceira desse tipo de empreendimento para determinar se são considerados viáveis na visão das construtoras e incorporadoras, responsáveis pela construção. Sendo assim, o presente trabalho aborda os aspectos da incorporação imobiliária de empreendimentos residenciais voltados para a baixa renda e participantes do Programa Minha Casa Minha Vida, apresentando a metodologia de uma análise econômico-financeira através do fluxo de caixa descontado e interpretação dos indicadores TIR, VPL e payback para a tomada de decisão.

Palavras chave: Déficit habitacional, Viabilidade, Retorno, Programa Minha Casa, Minha Vida, Incorporação Imobiliária. 


\section{Abstract}

Ozenda, Carolina. Igrejas, Rafael. Análise da Viabilidade EconômicoFinanceira para um empreendimento participante do Programa Minha Casa Minha Vida. Rio de Janeiro, 2015. 54 pages. Relatório Final de Estágio Supervisionado II - Departamento de Administração. Pontifícia Universidade Católica do Rio de Janeiro.

The construction sector is relevant to Brazil's growth, as it plays an important role for the country's creation of jobs and housing development. In an attempt to reduce the housing deficit, the government has made available resources to stimulate the Brazilian real estate market through the Programa Minha Casa, Minha Vida (My House, My Life) program, a housing project for lower income earners.

Thus, it is necessary to conduct an economic and financial analysis of this type of project in order to assess if they should be considered to be feasible under both the construction corporations' and real estate development companies' perspective, considering that they are the ones responsible for the construction. Therefore, this paper discusses the real estate development's aspects of residential projects focused on low-income earners participants of the Minha Casa Minha Vida (My House, My Life) program, presenting an economic and financial analysis methodology using the discounted cash flow and interpretation of the IRR, NPV and payback indexes as elements for the decision making.

Keywords: Housing deficit, Feasibility, Return, Programa Minha Casa, Minha Vida (My House, My Life), Real Estate Development 


\section{Sumário}

1 O problema 11

1.1. Introdução 11

1.2. Objetivo Final 14

1.3. Objetivos Intermediários 14

$\begin{array}{ll}\text { 1.4. Relevância do Estudo } & 14\end{array}$

2 Referencial Teórico 16

2.1. Incorporação Imobiliária 16

2.2. Sociedade de Propósito Específico 17

2.3. Programa "Minha Casa, Minha Vida" 18

$\begin{array}{ll}\text { 2.3.1. Características } & 19\end{array}$

2.3.2. Resultados do PMCMV 21

2.4. Financiamento 23

2.4.1. Financiamento no Programa "Minha Casa, Minha vida". 25

2.5. INCC 27

3 Metodologia 28

3.1. Fluxo de Caixa Descontado 29

3.2. Custo do Capital 29

3.2.1. WACC / CMPC 30

3.2.2. CAPM 30

3.3. Valor Presente Líquido 32

3.4. Taxa Interna de Retorno 32

3.5. Payback 33

4 Estudo de Caso 34

4.1. Características do empreendimento 34

4.2. Orçamento 35

4.3. Cronograma Físico-Financeiro da Obra 36

$\begin{array}{ll}\text { 4.4. Financiamento } & 37\end{array}$ 
4.5. Fluxo de Caixa 38

4.6. Análise dos resultados 48

5 Conclusão $\quad 50$

5.1. Sugestões e recomendações para novas pesquisas 51

6 Bibliografia 52

7 Anexo 1 


\section{Lista de figuras}

Figura 1: Déficit Habitacional Brasileiro, 2010.

Figura 2: Total de unidades entregues até abril/2014. 21

Figura 3: Unidades PMCMV contratadas, concluídas e entregues até 30/04/2014.

Figura 4: - Valor financiado x unidades contratadas. 25

Figura 6: Análise do VPL x TIR. 49

\section{Lista de Tabelas}

Tabela 1 - Cronograma físico-financeiro 36

$\begin{array}{ll}\text { Tabela } 2 \text { - Características do financiamento } & 37\end{array}$

Tabela 3 - Fluxo de desembolso para o financiamento da obra 38

Tabela 4 - Valor das unidades $\quad 41$

Tabela 5 - Características do fluxo de receitas 41

Tabela 6 - Fluxo de receitas 42

Tabela 7 - Beta 43

Tabela 8 - Média de rentabilidade dos títulos públicos 44

Tabela 9 - Prêmio de risco $\quad 44$

Tabela 10 - Tabela CAPM 45

Tabela 11 - Tabela WACC 46

$\begin{array}{ll}\text { Tabela } 12 \text { - Fluxo de Caixa } & 47\end{array}$ 


\section{Lista de Equações}

Equação 1- Fluxo de Caixa Descontado $\quad 29$

Equação 2- Custo médio Ponderado do Capital 30

$\begin{array}{ll}\text { Equação 3- Custo do capital próprio } & 31\end{array}$

Equação 4- Método do Valor Presente Líquido 32

Equação 5- Método do Payback descontado 33

Equação 6- Beta alavancado 43

Equação 7- Modelo CAPM + Risco Brasil 45

\section{Lista de Abreviaturas}

ABECIP - Associação Brasileira das Entidades de Crédito Imobiliário e Poupança

ADEMI - Associação de Dirigentes de Empresas do Mercado Imobiliário

BCB - Banco Central do Brasil

CAPM - Capital Asset Pricing Model

CBIC - Câmera Brasileira da Indústria da Construção

CDS - Credit Default Swap

CEF - Caixa Econômica Federal

CIBRASEC - Companhia Brasileira de Securitização

CNI - Confederação Nacional da Indústria

EMBI - Emerging Markets Bond Index Plus

FAR - Fundo de Arrendamento Residencial

FED - Federal Reserve

FGTS - Fundo de Garantia do Tempo de Serviço 
FGV - Fundação Getúlio Vargas

FME - Fundo Especial Mobiliário

IBGE - Instituto Brasileiro de Geografia e Estatística

INCC - Índice Nacional de Centro de Custo

IPCA - Índice Nacional de Preços ao Consumidor

PAC - Programa de Aceleração do Crescimento

PBQP-H - Programa Brasileiro de Qualidade e Produtividade

PIB - Produto Interno Bruto

PMCPMV - Programa Minha Casa, Minha Vida

PNAD - Pesquisa Nacional por Amostra de Domicílio

PNHR - Programa Nacional de Habitação Rural

PNHU - Programa Nacional de Habitação Urbana

SEBRAE - Serviço Brasileiro de Apoio às Micro e Pequenas Empresas

SEDHAB - Secretaria de Estado de Gestão do Território e Habitação

SFH - Sistema Financeiro de Habitação

SFI - Sistema Financeiro Imobiliário

SPE - Sociedade de Propósito EspecíficaTIR - Taxa Interna de Retorno

TR - Taxa Referencial

VGV - Valor geral de vendas

VPL - Valor Presente Líquido

WACC - Weighted Average Cost of Capital 


\section{0 problema}

\subsection{Introdução}

A década passada foi marcada por estabilidade econômica que possibilitou o crescimento do Brasil. Dentre os motivos que colaboraram a estabilidade, alguns deles podem ser destacados: redução e controle da inflação, diminuição das taxas de juros (Banco Central, 2015) e políticas governamentais de distribuição de renda que promoveram o avanço da classe social (Centro Políticas Sociais da Fundação Getúlio Vargas, 2015).

A construção civil contribui tanto para o papel econômico quanto para o setor social. Segundo Goldman (2015), o mercado da construção é relevante na geração de empregos e de riqueza econômica para a sociedade.

Assim, a construção civil é considerada um setor estratégico para o desenvolvimento da economia, pois possui número elevado de mão de obra empregada, considerável participação no Produto Interno Bruto (PIB) e diversidade de subsetores a ela interligada. Segundo a Confederação Nacional da Indústria (CNI), a construção civil é fundamental para o progresso nacional, uma vez que edifica obras que sustenta o progresso. A partir dela um país se desenvolve, por suas obras de infraestrutura e moradias, criando renda e empregos para a população e inovando recursos tecnológicos, através do desenvolvimento dos processos construtivos.

Nos últimos anos, o setor da construção civil vem apresentando importante papel como fonte de investimento da economia brasileira. Em levantamento da Câmera Brasileira da Indústria da Construção Civil, os setores envolvidos na construção representam 5,3\% de todo PIB e emprega 3,4 milhões de pessoas, segundo dados do Instituto Brasileiro de Geografia e Estatística IBGE (2013).

A diversidade de subsetores da construção civil é formada pelos seus meios de atuação. Segundo o Serviço Brasileiro de Apoio às Micro e Pequenas Empresas (SEBRAE) esses são compreendidos por: subsetor de matérias e construção, responsável pela execução de fundações, estruturas, controles tecnológicos, geotecnia, lançamento de concreto, formas, sistemas de ar condicionado, impermeabilização; subsetor de edificações, responsável pelos 
edifícios residenciais, comerciais, shoppings, incorporações, hotéis; subsetor de construções pesadas, responsável pelas obras de rodoviárias, saneamento, usinas hidrelétricas, usinas nucleares, aeroportos, plataformas, obras portuárias, pontes e viadutos, entre outros; e o subsetor de montagem industrial, responsável pelas fábricas.

Visando o desenvolvimento de todos esses integrantes, o Governo Federal Brasileiro criou, em 2007, o Projeto de Aceleração do Crescimento, o PAC, o qual seu principal objetivo é a retomada do planejamento e execução de infraestrutura social, urbana, logística e energética para o desenvolvimento acelerado e sustentável (Ministério do Planejamento, 2015). Apesar de não ter cumprido com todas as promessas idealizadas, pode-se citar dois subprogramas que ajudaram na estruturação da construção civil: "Plano Brasil Maior" e o "Minha Casa, Minha Vida".

O programa "Brasil Maior" promoveu o aumento das contratações formais nas construtoras devido à desoneração da folha de pagamento. Esse incentivo na geração de emprego ocorreu devido à mudança da base de cálculo da Contribuição Previdenciária, a qual substitui o valor total da folha de pagamento, alíquota de $20 \%$, pelo valor da receita bruta, alíquota de $2 \%$. O grande diferencial entre as metodologias é que às construtoras apenas precisarão recolher a contribuição previdenciária quando tiverem receita. O objetivo principal do programa com essa alteração tributária foi de reduzir os custos de produção no Brasil, para garantir a competitividade com concorrentes internacionais, devido à alta carga tributária brasileira.

Já o Programa Minha Casa, Minha Vida (PMCMV) voltado para habitação popular aperfeiçoou os critérios de financiamento, ajudando o acesso dos recursos do FGTS e à taxas de juros diferenciadas. No entanto, apesar do programa ter reduzido em cinco anos, $8 \%$ do déficit habitacional, segundo levantamento realizado pela FGV para o Sinduscon, estima-se que ainda são necessários $R \$ 76$ bilhões ao ano de investimentos até 2024 , pois existem 5,2 milhões de lares considerados em condições precárias, ou famílias que moram em favelas e dividem apartamentos. (Pesquisa Nacional por Amostra de domicílio, 2013 - PNAD).

Hoje o país é marcado por um déficit habitacional para a população de baixa renda. O direito à moradia está citado no Art. 6 da Constituição Federal, mas segundo o IBGE 5.792.508 as pessoas vivem esse problema, evidenciando que este direito social ainda não é efetivo entre toda a população. Ainda conforme o IBGE o ônus excessivo com aluguel, coabitação familiar e habitação 
precária são os principais motivos desse déficit. O ônus excessivo com aluguel se refere a famílias de baixa renda (até 3 salários) que gastam aproximadamente $30 \%$ da renda familiar com o pagamento do aluguel. A coabitação familiar se refere a famílias que dividem uma mesma moradia ou vivem em cortiços. Por último a habitação precária que corresponde a habitações improvisadas. Estudos realizados pela PNAD mostram que a população necessita de oferta habitacional.

Percebe-se que o país tem uma grande demanda por habitações populares sendo necessário o investimento nesse subsetor da construção civil, o de edificações, conhecido também como mercado imobiliário. Para Bueno (2012), a estabilidade dos preços, crescimentos econômicos, do emprego e da renda da população, contribuem para estimular o consumo e dinâmica deste mercado. Assim, o seu desempenho é influenciado por diferentes fatores macroeconômicos, como a estabilidade econômica, inflação, nível das taxas de juros e renda per capita (Incorporadora EZTEC, 2015).

A taxa de juros influencia na liquidez dos meios de pagamento, sendo um fator crucial na tomada de decisão de consumo e de investimentos das empresas. Com os juros altos, há a redução do acesso a financiamentos, seja por pessoa física ou jurídica afetando diretamente o mercado imobiliário. Outra variável a qual o setor se torna refém é a inflação alta, pois reduz o nível das atividades econômicas, o consumo e os investimentos.

No mercado imobiliário, a alta da inflação também afeta diretamente o Índice Nacional da Construção Civil (INCC) que é um indexador dos custos de construção e dos recebimentos futuros nas vendas a prazo a serem reajustados no tempo.

Sendo assim, por mais que o cenário brasileiro seja favorável para o investimento em habitações populares, as construtoras e incorporadoras imobiliárias precisam se precaver dos fatores macroeconômicos. Dado as incertezas do mercado (instabilidade econômica, juros, inflação, alta dos preços) e os custos da construção (os trâmites para o processo de incorporar, construir, vender são custosos) muitas delas apresentam dificuldades em viabilizar empreendimentos residenciais de baixo custo.

Nesse sentido, é devido questionar sobre os critérios que devem ser adotados para a viabilidade de um projeto. Logo, é primordial realizar a análise econômico-financeira através do fluxo de caixa descontado dos empreendimentos, sendo esse o motivo do presente estudo, permitindo a tomada de decisão para o investimento. 


\subsection{Objetivo Final}

O Objetivo final deste trabalho é realizar e avaliar a viabilidade econômica - financeira de um projeto de habitação popular dentro do programa "Minha casa, Minha vida".

\subsection{Objetivos Intermediários}

Os objetivos intermediários são compreender o conceito de incorporação imobiliária e as variáveis que influenciam no seu ciclo de vida.

Após a contextualização sobre $o$ assunto, entender os pontos principais que determinam a vida financeira de um projeto residencial voltado para baixa renda. Para isso, será adotada a metodologia do fluxo de caixa descontado e análise dos seus resultados como o VPL, TIR e o payback, avaliando os riscos que podem ser cometidos na viabilidade do empreendimento.

\subsection{Relevância do Estudo}

O setor da construção civil é relevante para o crescimento do Brasil, pois gera empregos e renda à população, além de servir como pilar para o desenvolvimento habitacional do país.

Sua importância, sob o ponto de vista econômico, é facilmente evidenciada pelo peso dos indicadores em relação à participação no PIB, na produção e no emprego (Kureski, 2008).

O setor possui a capacidade de absorção de grande contingente de mão de obra com pouca ou sem nenhuma formação, o que acaba ajudando na redução das taxas de desemprego. De acordo com o IBGE, em 2013 a construção civil empregava, formalmente, cerca de 3,4 milhões de pessoas no Brasil, o que representa 7,4\% da população economicamente ativa. Segundo a Câmera Brasileira da Indústria da Construção (CBIC), as obras do PAC e os investimentos no PMCMV contribuíram para impulsionar as atividades na construção civil e favorecer a contratação de mão de obra.

O PMCMV ainda possui importância social em relação ao déficit habitacional presente no país, já que estimula a construção de habitações populares, que por consequência, promove a redução do déficit. Em parceria 
com o Ministério das Cidades e com a Caixa Federal, para incentivar as incorporadoras e construtoras a participarem do programa, foi criado uma linha de financiamento específico para os projetos residenciais populares, além de ter facilitado o acesso ao crédito da população de baixa renda garantindo os compradores para os empreendimentos futuros. Com essas iniciativas o mercado imobiliário se torna protagonista para o combate do déficit habitacional. 


\section{Referencial Teórico}

\subsection{Incorporação Imobiliária}

Segundo a Receita Federal, considera-se incorporação imobiliária a atividade exercida com o intuito de promover e realizar a construção, para alienação total ou parcial, de edificações ou conjunto de edificações compostas de unidades autônomas, sob o regime de condomínio (art. 28, § único, Lei Federal no 4.591).

O condomínio é formado pelas edificações ou conjunto de edificações, de um ou mais pavimentos, construídos sob a forma de unidades residenciais ou comerciais, podendo ser comercializadas como um todo ou isoladamente, constituindo cada unidade uma propriedade autônoma. (Lei Federal no 4.591)

A mesma lei determina o incorporador como pessoa física ou jurídica, que mesmo não realizando a construção do empreendimento, se compromete a efetuar a venda das frações do terreno as quais representam as unidades autônomas. Tal conceituação ainda pode ser compreendida pela Lei de Condomínios e Incorporações, pois afirma que a incorporação é a atividade que será realizada e não a qualificação do sujeito que a promove. Sendo assim independe se o incorporador é uma pessoa física, profissional da área ou se é jurídica.

Segundo Junqueira (2005), muitas vezes o incorporador é o próprio dono do terreno, que pretende promover a edificação ou condomínio. Isso demonstra que qualquer pessoa da sociedade pode se tornar responsável pela cadeia produtiva de uma incorporação desde que tenha a preocupação de gerir o capital da forma mais rentável, transformando o capital - dinheiro em capital mercadoria (Ribeiro, 1997).

A comercialização legal das unidades de um empreendimento pode ser realizada ainda na planta ou em fase de construção (Franco, Gondo, 1991). Logo a incorporação permite a entrada de recebíveis durante todo o processo de um projeto, garantindo a dinâmica econômica - financeira, pois legalmente as unidades podem ser vendidas a prestações. 


\subsection{Sociedade de Propósito Específico}

As incorporações imobiliárias executam seus empreendimentos através da constituição de Sociedade de Propósito Específica (SPE). Assim uma incorporadora imobiliária apresenta várias SPE's em seu portfólio.

SPE "é um modelo de organização empresarial pelo qual se constitui uma nova empresa limitada ou sociedade anônima com um objetivo específico." (SEBRAE). Possui atividade restrita, podendo ter prazo de duração determinado e sua principal utilidade é de isolar o risco financeiro da atividade a que se destina.

A Lei Complementar o 128 define a Sociedade de Propósito Específico como uma sociedade com personalidade jurídica, escrituração contábil própria e demais características comuns às empresas limitadas ou Sociedades Anônimas. É uma sociedade patrimonial que pode adquirir bens móveis, imóveis e participações. Sendo assim, ao ser criada, passa a responder pelos direitos e obrigações do empreendimento pela qual foi constituída. Seu capital social é formado pela integralização dos bens móveis, imóveis e dinheiro dos sócios.

A constituição da SPE é formalizada através do Contrato Social entre os sócios, determinando quais serão as cláusulas a serem seguidas segundo a legislação que regulamenta o tipo societário adotado. Segundo Boscardin, as principais motivações para as incorporados imobiliárias utilizarem esses regimes são a independência administrativa e fiscal do empreendimento em relação aos demais, maior agilidade em adquirir o financiamento bancário, flexibilidade na busca de parcerias e acionistas e maior transparência entre as partes envolvidas.

No caso do mercado imobiliário, o grande marco para a utilização da SPE foi à falência da Construtora Encol, que deixou centenas de empreendimentos imobiliários inacabados e aproximadamente 42 mil famílias lesadas, necessitando de uma política de proteção aos mutuários. Essa política foi aperfeiçoada através da própria SPE e do Patrimônio de Afetação (assegurar os direitos dos adquirentes de unidades autônomas de edifício em construção no caso de falência ou insolvência civil do incorporador). Boscardin ressalta que são modelos complementares, pois enquanto o patrimônio de afetação proporciona garantias ao comprador caso haja falência do incorporador, a SPE é uma empresa criada para ter suas próprias regras independente da incorporadora 
imobiliária. Quando a incorporadora adota o patrimônio de afetação em suas SPE's, possuem as seguintes vantagens:

"a) diminuição de riscos e melhor segurança para seus clientes e para a instituição financiadora da obra, assegurando o patrimônio do empreendimento dos bens do incorporador em caso de falência;

b) apuração individualizada no lucro de cada empreendimento;

c) transmite maior transparência na gestão de seus empreendimentos perante as partes envolvidas;

d) obtém redução da carga tributária de $6 \%$ para $4 \%$, através do Regime Especial de Tributação da Lei Federal no $10.931 / 2004$, que em seu artigo $4^{\circ} \mathrm{e}$ seguintes estabeleceu o percentual de $4 \%$ da receita recebida, correspondendo ao pagamento mensal e unificado do Imposto de Renda das Pessoas Jurídicas (IRPJ); Contribuição para os Programas de Integração Social e de Formação do Patrimônio do Servidor Publico (PIS/PASEP); Contribuição Social sobre o Lucro Líquido (CSLL) e Contribuição para Financiamento da Seguridade Social (COFINS); e

e) se o empreendimento constituído do patrimônio de afetação for enquadrado nas regras do programa do Governo Federal chamado Minha Casa, Minha Vida, o incorporador pagará apenas $1 \%$ de carga tributária sobre 0 faturamento total da obra, c onforme determinado pela Medida Provisória ํㅡ 497, de 27 de julho de 2010 e estendido até o ano de 2018 para imóveis em valor de até $\mathrm{R} \$ 100.000,00$." (Boscardin, 2015).

Como são empresas independentes, cada SPE do portfólio da incorporadora pode assinar contrato com diferentes construtoras, afinal cada um terá sua especificação. As incorporadoras tendem a fechar contratos com diversas construtoras, pois ampliam seu leque de investimento, diluindo os riscos de construção.

\subsection{Programa "Minha Casa, Minha Vida"}

Devido ao incentivo do governo em habitações populares, muitas incorporadoras constituem SPE para participar do Programa Minha Casa, Minha Vida.

O Programa Minha casa, minha vida (PMCMV) foi criado em 2009 e consiste no programa habitacional do Governo Federal do Brasil para permitir acesso ao crédito imobiliário. O programa apresenta-se como uma estratégia para recuperar o passivo social relacionado ao déficit habitacional (SEDHAB Secretária de Estado de Gestão do Território e Habitação, 2015), ou seja, através de mudanças no financiamento imobiliário busca alcançar as camadas mais baixas da população brasileira. 
O PMCMV é composto por dois subprogramas: o Programa Nacional de Habitação Urbana (PNHU) e o Programa Nacional de Habitação Rural (PNHR). Porém o presente trabalho abordará o PNHU.

\subsubsection{Características}

A lei $n=12.424$ determina as entidades participantes para o funcionamento do PMCMV, são elas: órgão criador, gestor da aplicação, agente operador, agentes financeiros, entidades organizadoras e os beneficiários.

- Órgão criador: representado pelo poder executivo, responsável pela determinação dos beneficiários e atualizações dos limites da renda familiar;

- Gestor da aplicação: representado pelo Ministério das Cidades, determina todas as regras, condições, diretrizes e avaliação do programa;

- Agente operador: representado pela Caixa Econômica Federal é o agente gestor dos recursos do programa, sendo esses o Fundo de Arrendamento Residencial (FAR) e o Fundo de Garantia do Tempo de Serviço (FGTS).

- Agentes financeiros: representado pela Caixa Econômica Federal e pelo Banco do Brasil financiam tanto a pessoa física (beneficiários) como a pessoa jurídica (construtora / incorporadora). São responsáveis pela análise financeira e jurídica das SPE's assim como pelo acompanhamento da execução das obras.

- Entidades Organizadoras: representado pelas incorporadoras imobiliárias, constituem uma SPE, definem os projetos, a construtora e comercialização das unidades.

- Beneficiários: representado pelas pessoas físicas que adquirem as unidades.

Conforme o Ministério do Planejamento, o PMCMV, destinado a habitações urbanas, foi inicialmente dividido em duas fases. A primeira tinha como proposta contratar um milhão de moradias para famílias com renda de até dez salários mínimos, fracionando $\mathrm{R} \$ 34$ bilhões pelas estimativas de déficit habitacional em cada uma das regiões: $37 \%$ para o sudeste, $34 \%$ para o Nordeste, $12 \%$ para o Sul, $10 \%$ para o Norte e $7 \%$ para o Centro Oeste. Já na 
segunda fase, os valores das rendas familiares foram reajustados ampliando o escopo do PMCMV. Agora a segmentação é determinada da seguinte forma: faixa 1 (famílias com renda até $R \$ 1.600,00$ ), faixa 2 (famílias com renda entre $R \$ 1601,00$ a $R \$ 3.275,00$ ), faixa 3 (famílias com renda entre $R \$ 3.275,01$ e $R \$$ $5.000,00)$.

A figura a seguir mostra o déficit brasileiro por região em 2010, ano posterior à criação do PMCMV. Percebe-se que a distribuição da primeira etapa do programa faz sentido ao buscar atender as regiões de acordo com 0 porcentual de déficit.

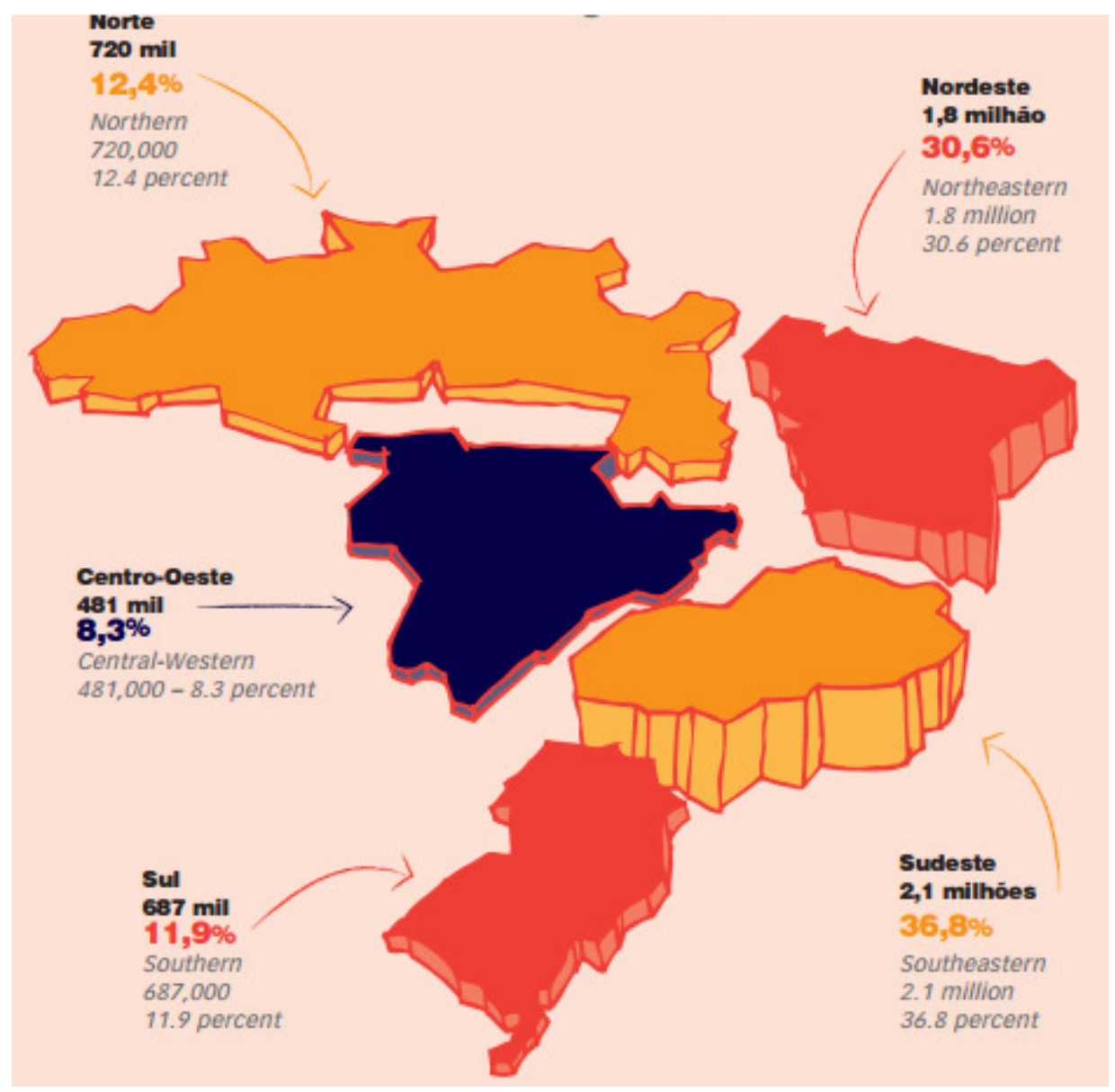

Figura 1: Déficit Habitacional Brasileiro, 2010.

Fonte: Fundação João Pinheiro, com base nos dados do Censo Demográfico de 2010.

Os recursos para os financiamentos podem ser pelo FAR ou pelo FGTS. De acordo com a Caixa, o FAR busca atender famílias que estão na faixa 1 e os recursos são transferidos a partir do Orçamento Geral da União; não há taxas de juros, o prazo da alienação são de 120 meses e as prestações limitadas em 5\% da renda familiar mensal; os recursos são direcionados à moradias entre $R \$$ $49.000,00$ e $R \$ 76.000,00$. Já o FGTS atende os financiamentos das outras duas 
faixas com taxas de juros diferenciadas, prazo da amortização de até 360 meses e o valor máximo de aquisição é de $\mathrm{R} \$ 190.000,00$.

\subsubsection{Resultados do PMCMV}

Pela Secretaria Municipal de Habitação, o programa tem como meta a construção de moradias para famílias que ganham até $R \$ 5$ mil. Até o final de abril 2014, conforme a Caixa Econômica Federal foram entregues 1,7 milhão de moradias, gerando empregos e incremento na cadeia produtiva da construção civil. A concentração de unidades entregues por região pode ser analisada na figura 2:

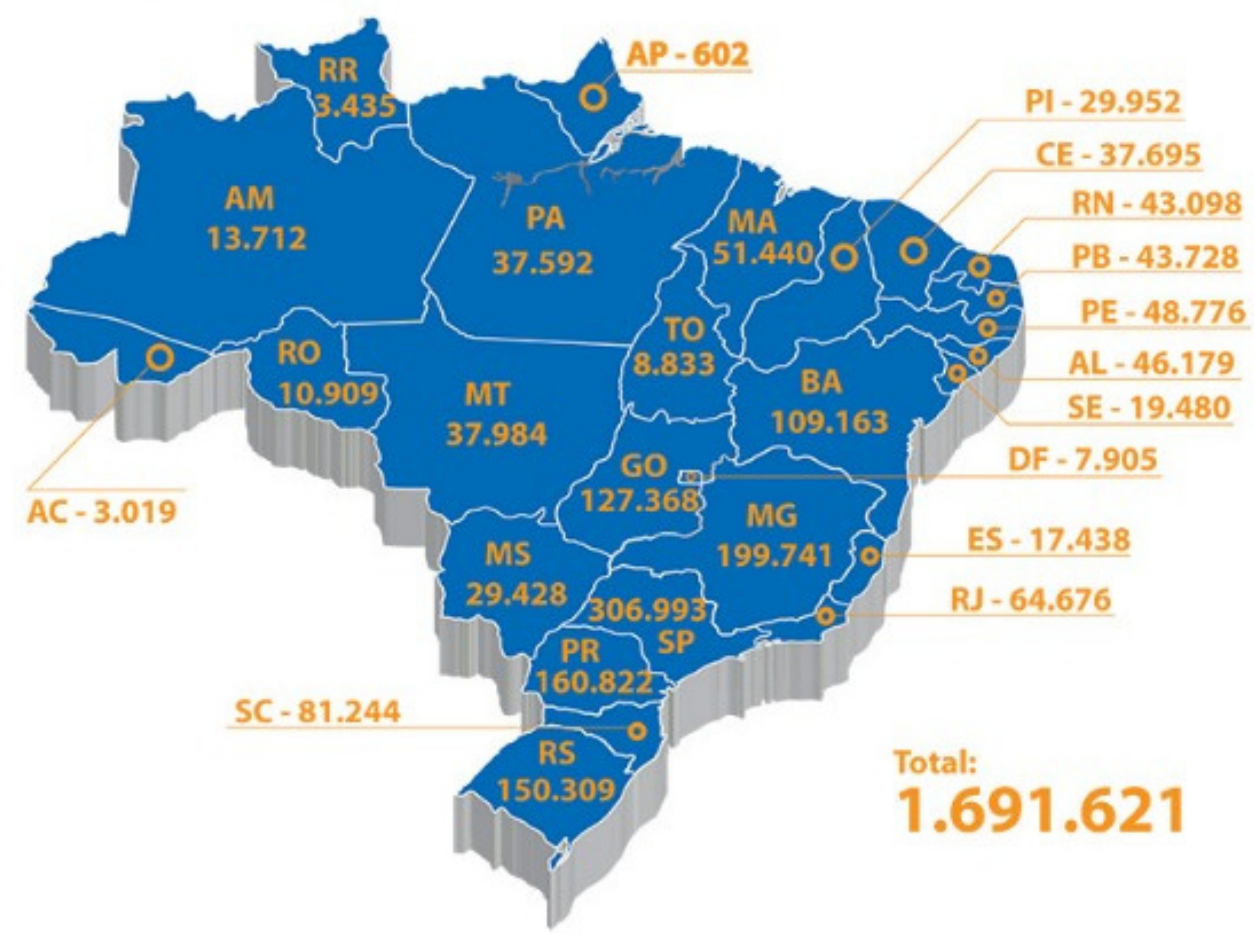

Figura 2: Total de unidades entregues até abril/2014.

Fonte: Secretária Municipal de Habitação - Resultados dos últimos 5 anos até abril/ 2014

A Associação Brasileira das Entidades de Crédito Imobiliário e Poupança (Abecip) divulgou o número da concentração de unidades contratadas, entregues e concluídas distribuídas pelas faixas do PMCMV nos últimos 5 anos: 


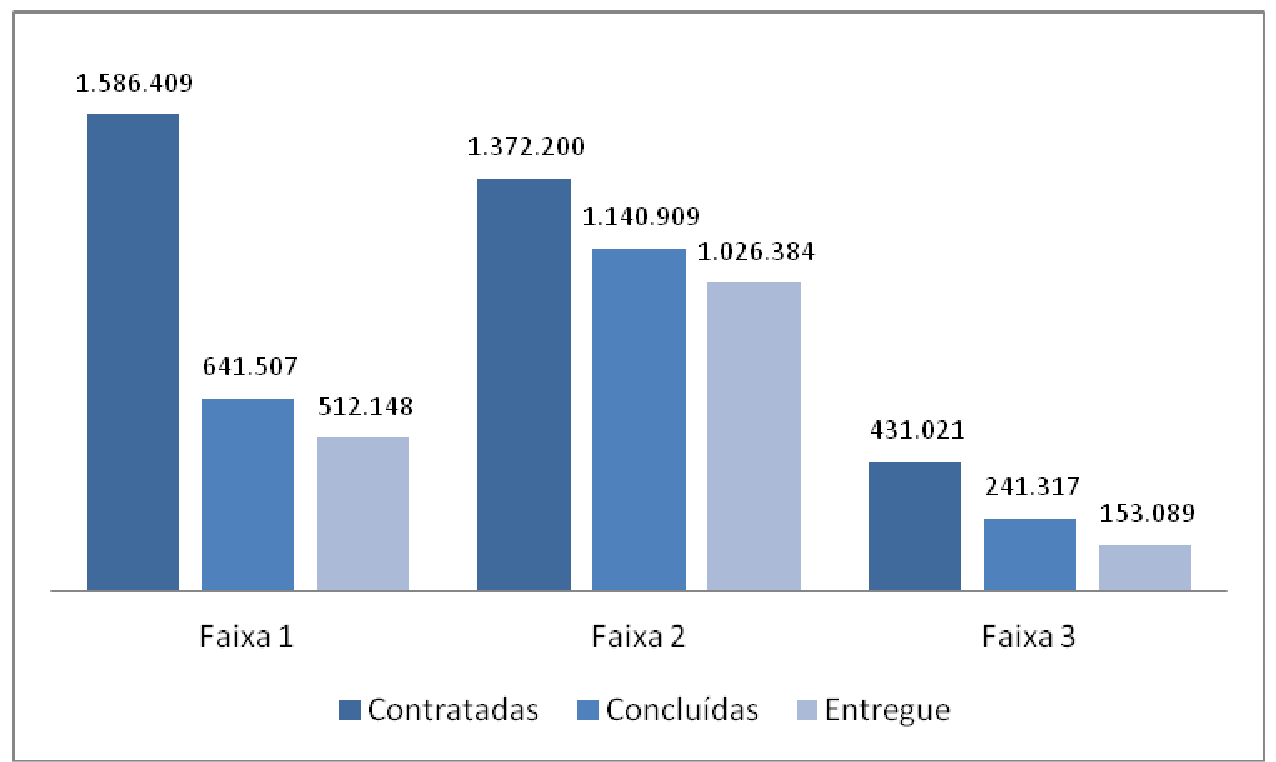

Figura 3: Unidades PMCMV contratadas, concluídas e entregues até 30/04/2014.

Fonte: própria a partir dos dados da Abecip (2014).

Pela figura pode-se perceber que a maior contratação de empreendimentos está na faixa 1 , porém esses foram os que proporcionalmente tiveram um menor número de projetos concluídos e entregues. Segundo o Sinduscon esse fato ocorre pelo atraso nos pagamentos para as construtoras que executam as obras, devido à inadimplência da população e atrasos da liberação dos recursos pelo governo. Com esses atrasos, pode haver uma redução no capital de giro das construtoras responsáveis afetando o caixa das empresas, podendo causar demissões dos funcionários e paralisação das obras.

Outro ponto relevante na construção de empreendimentos nessa faixa é o orçamento apertado. Como o preço da venda das unidades é mais baixo, a entrada de recebíveis também é mais baixa, e para viabilizar o projeto é necessário ter um orçamento de construção enxuto capaz de atender as necessidades do empreendedor e dos consumidores.

Assim, mesmo com a preocupação do governo em reduzir o déficit dessa faixa, hoje, na visão das construtoras e incorporadoras, é melhor investir nos empreendimentos das faixas 2 e 3, pois a margem de risco não é tão reduzida, onde qualquer inadimplência, erro no orçamento e na execução podem comprometer na viabilidade do empreendimento. 


\subsection{Financiamento}

De acordo com a Caixa, poucos indivíduos, independente da classe social, possuem a capacidade de adquirir um bem imóvel à vista, diante do custo de produção da habitação. Assim, viabilizar o acesso à moradia é uma importante ferramenta para o setor social, o qual vem sendo possível através do financiamento junto às instituições financeiras visando aquecer a indústria da Construção Civil.

O início do sistema de financiamento no Brasil pode ser marcado pela criação do "Sistema Financeiro de Habitação" em 1964, o qual se baseava na concessão de crédito habitacional com fontes próprias de recursos seja pela caderneta de poupança ou pelo FGTS. Apesar de certo aumento das moradias, tal sistema apresentou falhas que contribuíram para o baixo desenvolvimento habitacional. Em estudo realizado pelo Banco Central, Costa (2004) afirma que as propostas governamentais nesse assunto não estavam sendo eficazes, pois não atingiam o principal objetivo que era 0 de implementar 0 acesso da população ao financiamento habitacional, ou seja, a maioria das famílias brasileiras continuavam sem acesso ao crédito. Os fatores que colaboraram para o fracasso do sistema foram: taxa de juro constante; falta de comunicação entre o SFH e os demais segmentos do mercado de capitais; permanência incerta dos depósitos nos fundos de financiamento do crédito (captação dos recursos nos curtos e médios prazos e empresta-os no longo prazo); comportamento prócíclico (quando aumenta a renda disponível das famílias, também aumenta a captação para o sistema, porém em períodos recessivos, os saques são maiores que os depósitos). Além das próprias fraquezas do sistema, os anos 80 e 90 foram marcados por crise política e econômica que dificultaram o acesso da população ao crédito imobiliário, pois a inflação alta da época ocasionou juros altos.

A necessidade de repensar a política habitacional do país a partir da crise do sistema anterior coincidiu com o início do período de estabilização no final dos anos 90. Assim com perspectivas otimistas para um reaquecimento do setor imobiliário, em 1997 foi criado o novo modelo: "Sistema Financeiro Imobiliário" (SFI).

O modelo institucional do SFI possui relações diretas com a economia de mercado, ou seja, suas operações são feitas de acordo com as condições do mercado em um determinado momento. Assim os recursos são oriundos das 
caixas econômicas, bancos comerciais, bancos de investimento, sociedades de crédito imobiliário, associações de poupança de iniciativas privadas, entre outros, sendo independente dos cofres públicos. O SFI apresenta como pontos principais a securitização dos créditos imobiliários e maior segurança jurídica dos contratos.

A securitização é coordenada pelas companhias securitizadoras e trata do processo de transformação dos créditos imobiliários em títulos dominados Certificados de Recebíveis Imobiliários a serem negociados no mercado financeiro de capitais (Companhia Brasileira de Secutirização - CIBRASEC), o que significa transformar a dívida em títulos negociáveis no mercado de capitais. Pelo Bovespa esse conceito é o mesmo que debênture: "título de dívida, de médio e longo prazo, que confere a seu detentor um direito de crédito contra a companhia emissora", assim a companhia emissora consegue obter recursos sem prejudicar o índice de endividamento.

Segundo a Associação Brasileira das Entidades de Crédito Imobiliário e poupança - ABECIP (1997):

"Securtitização é a operação pela qual créditos imobiliários, adquiridos no mercado primário, junto às entidades financiadoras de imóveis, são expressamente vinculados à emissão de uma série de Certificados de Recebíveis Imobiliários (CRI's). A securitização é formalizada mediante a lavratura, por uma companhia securitizadora, de um "termo de securitização".A operação se conclui com a venda do CRI aos investidores" (ABECIP).

A segurança jurídica nos contratos foi garantida pela alienação fiduciária que é definida como a garantia da dívida do devedor através da transferência de um bem ao credor.

"A alienação fiduciária é o instituto pelo qual o devedor de uma obrigação principal transfere ao credor a propriedade de um determinado bem, sob condição resolúvel expressa, ou seja, uma vez quitada a dívida perante o credor, fiduciário, resolvida estará também a propriedade que lhe foi transferida em garantia do cumprimento da obrigação. Concedido o crédito, a pessoa toma posse direta do bem e aliena-o fiduciariamente ao credor". (Camargo Dantzger, 2005)

Segundo fonte da Associação Brasileira de Crédito Imobiliário (Abecip), em 2014 as operações contratadas somaram $R \$ 112,9$ bilhões e ao todo financiaram 538.347 imóveis, demonstrando um crescimento em relação ao ano anterior, que apresentou $R \$ 109$ bilhões equivalentes a 529.797 unidades. $O$ gráfico abaixo evidencia esse crescimento do financiamento e do acesso ao 
crédito imobiliário, incentivando o aquecimento do mercado, demonstrado pela curva do número de unidades.

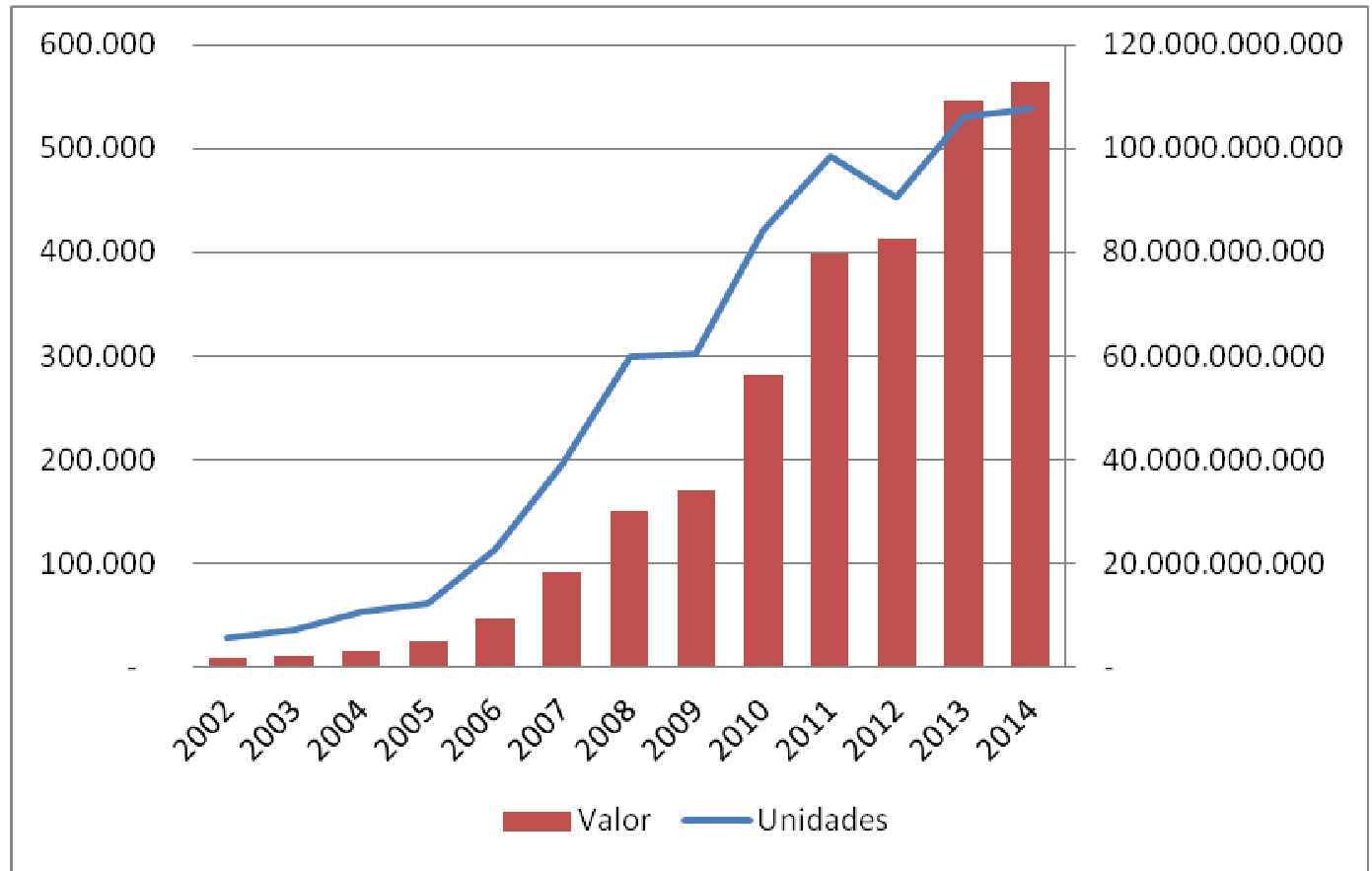

Figura 4: - Valor financiado x unidades contratadas.

Fonte: Gráfico construído a partir dos dados da Abecip.

\subsubsection{Financiamento no Programa "Minha Casa, Minha vida”.}

O PMCMV teve como foco $\mathrm{o}$ atendimento às famílias de baixa renda dividindo-as em três faixas de acordo com as suas rendas. Segundo a Caixa Econômica, o programa permite a aquisição de um imóvel através do financiamento pelo Fundo de Arrendamento Residencial (FAR) ou FGTS, sendo dependente dessa renda para estabelecer o teto máximo de financiamento. Esses variam de acordo com a região: $R$ \$ 190.000,00 para São Paulo, Brasília e Rio de Janeiro; $R \$ 170.000,00$ nas regiões com mais de um milhão de habitantes; $R$ \$ 145 mil nos municípios com população acima de 250 mil; $R$ \$ 115 mil nas cidades com mais de 50 mil habitantes e $R \$ 90$ mil nas demais regiões.

Para a população as vantagens são: caso a renda familiar não ultrapassar $30 \%$ dos rendimentos, o consumidor recebe o subsídio de $R \$ 18.000,00$ até $R \$$ $25.000,00$ e pode financiar $100 \%$ do imóvel; os juros são reduzidos em comparação aos outros sistemas de financiamento ficando entre 5\% e 8,16\%; isenção ou abatimento de taxas cartoriais para a aquisição de imóveis novos e prazo de até 360 meses. 
Os juros também são correspondentes à renda familiar agindo da seguinte forma: famílias até 3 salários - sem juros; famílias de 3 a 5 salários - juros de $5 \%$ + TR e famílias de 6 a 10 salários - juros de 6\% a 8,16\% + TR. A quitação do financiamento é feita pela tabela SAC, onde o sistema de amortização é constante diminuindo um percentual fixo da dívida desde 0 início do financiamento (CEF, 2015).

Para as construtoras e incorporadas, que é o caso a ser tratado, o financiamento ocorre pelo financiamento à produção através do Plano Empresário. Segundo a Cartilha de Financiamento Imobiliário do Sinduscon (2009), essa modalidade funciona para o PMCMV da seguinte maneira:

1. Construtoras apresentam projetos de empreendimentos às superintendências regionais da Caixa Econômica Federal (CEF).

2. A Caixa realiza pré-análise e autoriza o lançamento e a comercialização.

3. Após conclusão da análise e comprovação da comercialização mínima exigida, é assinado o Contrato de Financiamento à Produção.

4. Durante a obra, a CEF financia o mutuário pessoa física, o qual entra como recebível na construtora.

5. Os recursos são liberados conforme cronograma, após vistorias realizadas pela CEF.

6. Concluído o empreendimento, a construtora entrega as unidades aos mutuários.

A pré-análise realizada pela Caixa, presente no segundo passo sobre 0 funcionamento do financiamento, é composta por uma série de requisitos os quais devem ser atendidos pelas incorporadoras a fim de adquirir 0 financiamento, são eles:

- Análises cadastrais de todos os envolvidos;

- Análise de risco de crédito da construtora / incorporadora;

- Análise jurídica das partes e do empreendimento;

- Análise de viabilidade técnica de engenharia;

- Avaliação do Projeto de Crédito Imobiliário;

- Apresentação de alvará ou licença para construção, atualizado;

Conforme a Cartilha de Financiamento do Sinduscon (2009) o financiamento possui como público alvo as construtoras e incorporadoras certificadas pelo Programa Brasileiro de Qualidade e Produtividade do Habit. (PBQP-H). Suas principais características são: o contrato só será assinado 
quando a construtora / incorporadora comprovar a comercialização de pelo menos 30\% das unidades na planta; o limite financiável é de até $R \$ 100$ milhões e de até $100 \%$ do custo de construção, ou seja, os custos com aquisição do terreno, despesas de marketing, tributação, despesas cartoriais, entre outras não fazem parte desse valor; e os juros serão cobrados aproximadamente à uma taxa de $8 \%$ a.a + TR, dependendo do acordo entre as partes envolvidas.

A Caixa realiza o desembolso do financiamento através de parcelas mensais, de acordo com o cronograma físico-financeiro do empreendimento. $\mathrm{O}$ cronograma representa a porcentagem que a obra alcançou, ou seja, que executou uma etapa da construção e o quanto foi gasto em um determinado mês para realizar essas atividades. A Cartilha afirma que o desembolso é realizado em parcelas mensais, de acordo com as etapas previstas no cronograma físicofinanceiro da obra, devidamente executadas e atestadas, buscando respeitar o cronograma de desembolso do contrato de empréstimo. Segundo o Sinduscon, cabe à instituição financeira acompanhar o que foi realizado no mês para medir o valor adequado a ser liberado, assim normalmente há uma inconformidade de aderência no cronograma, já que o que foi executado normalmente não é a previsão inicial do contrato.

\subsection{INCC}

O Índice Nacional da Construção Civil (INCC) é utilizado como base de reajuste do valor do imóvel em construção (FGV, 2015). Como os preços de materiais e mão de obra sofrem reajustes ao longo da obra, modificando o valor do orçamento inicial; os preços dos imóveis também devem acompanhar essas alterações. O INCC tem como finalidade aferir a evolução dos custos de construção habitacional (FGV, 2015).

Assim, se o comprador financiar seu imóvel, mensalmente as parcelas serão reajustadas de acordo com o INCC modificando o saldo devedor. Logo, o montante final do imóvel não será o mesmo da assinatura do contrato de compra e venda. 


\section{Metodologia}

Para a elaboração de uma metodologia eficaz e definição de premissas, foi realizado um levantamento de dados primários. Essa pesquisa baseia-se na coleta de dados através de conversas, entrevistas e observação, sendo assim possível estabelecer parâmetros para a realização da análise econômicofinanceira.

A viabilidade econômica tem como objetivo criar valor para seus acionistas, portanto examina a capacidade de um projeto em gerar lucro e o retorno do seu capital investido.

Segundo Damodaram (2012), "um bom investimento é o investidor não pagar mais por um ativo do que seu valor justo". Assim é necessário avaliar e entender um ativo que será adquirido através do acompanhamento dos fluxos de caixa e da aplicação de métodos apropriados de decisão.

Para Braga (1995), a tomada de decisão é determinada por um processo o qual define onde, quando e quanto investir, sendo compreendido como Orçamento de capital. Ross (2013) conceitua essa ideia como a busca em determinar se o investimento ou projeto proposto valerá mais, depois de terminado, do que seu custo, indicando se é um bom negócio.

Samanez (2002) avalia o processo de decisões de procura e aquisições de ativos de longo prazo, a partir de cinco principais etapas:

1. Estimativa do fluxo de caixa esperados para o projeto;

2. Avaliação do risco do projeto e determinação da taxa de desconto;

3. Cálculo de indicadores econômicos;

4. Reconhecimento das limitações do método;

5. Tomada de decisão.

De acordo com Samanez (2002), o valor de projeto é baseado na sua capacidade de gerar fluxo de caixa futuro, conseguindo assim realizar comparações entre alternativas de investimento no tempo, onde os critérios de avaliação devem considerar os descontos (taxa de desconto) do fluxo. 


\subsection{Fluxo de Caixa Descontado}

O fluxo de caixa é compreendido pelas entradas e saídas de dinheiro ao longo do planejamento de um projeto, permitindo avaliar a rentabilidade e viabilidade econômica (Samanez, 2002). Assim, pode-se considerar que representa a renda econômica estimada através de operações futuras.

Damodaran (2012) afirma que o fluxo de caixa é o pagamento ou o recebimento de dinheiro em um determinado tempo futuro. Ao ser aplicado um desconto, a quantia é convertida no valor presente, permitindo que o investidor compare as quantias pelo tempo.

O fluxo pode ser calculado da seguinte maneira:

$$
\begin{aligned}
& \text { Valor do Ativo }=\sum_{t=1}^{t=n} \frac{C F t}{(1+r)^{t}} \\
& \text { Equação 1- Fluxo de Caixa Descontado } \\
& \text { Onde, CFt = Cash Flow (Fluxo de Caixa) no período } t . \\
& t=\text { vida útil do ativo. } \\
& r=\text { taxa de desconto refletindo o risco inerente aos fluxos de caixa estimados. }
\end{aligned}
$$

Segundo Ross (2013), o fluxo de caixa é a soma do fluxo de caixa dos credores e do fluxo de caixa dos acionistas, a qual reflete o fato de que uma empresa gera caixa a partir de suas atividades e que esse é usado para pagar os credores e acionistas. O fluxo de caixa dos credores são os juros pagos menos os novos empréstimos líquidos e o fluxo dos acionistas são os dividendos e juro sobre o capital próprio pago aos acionistas menos o aumento de capital.

\subsection{Custo do Capital}

O custo do capital é a taxa de retorno esperada para a rentabilidade oferecida nos mercados (Samanez, 2002).

Ainda pode ser compreendia como a taxa de desconto utilizada nos fluxos de caixa. O processo converte os fluxos de caixa futuros em fluxos de caixa presente, isso significa trazer o valor futuro de um ativo em valor presente. A taxa de desconto evidencia o grau de risco implícito em um fluxo, quanto maior for à taxa maior será o risco do projeto estudado. 
Conforme Samanez (2002), a taxa de desconto pode ser interpretada de duas maneiras: custo médio ponderado de capital (WACC) e custo de capital próprio (CAPM). Segundo Damodaran (2012), o risco do patrimônio líquido de uma empresa é medido pelo custo do capital próprio, enquanto o risco da empresa é calculado pelo custo do capital total, representado pela média ponderada do custo do capital próprio e do custo do capital de terceiros.

\subsubsection{WACC / CMPC}

O Weighted Average Cost of Capital (WACC) é o custo médio ponderado do capital (CMPC), onde a empresa é financiada ao mesmo tempo por capital próprio e capital de terceiros, ou seja, é uma taxa que pondera o custo de capital dos acionistas e o custo da dívida, representando o retorno esperado pela empresa. (Gitman 2010). O custo da dívida, o valor do capital próprio e o capital de terceiros devem ter seus valores proporcionais ao mercado.

A fórmula pode ser representada:

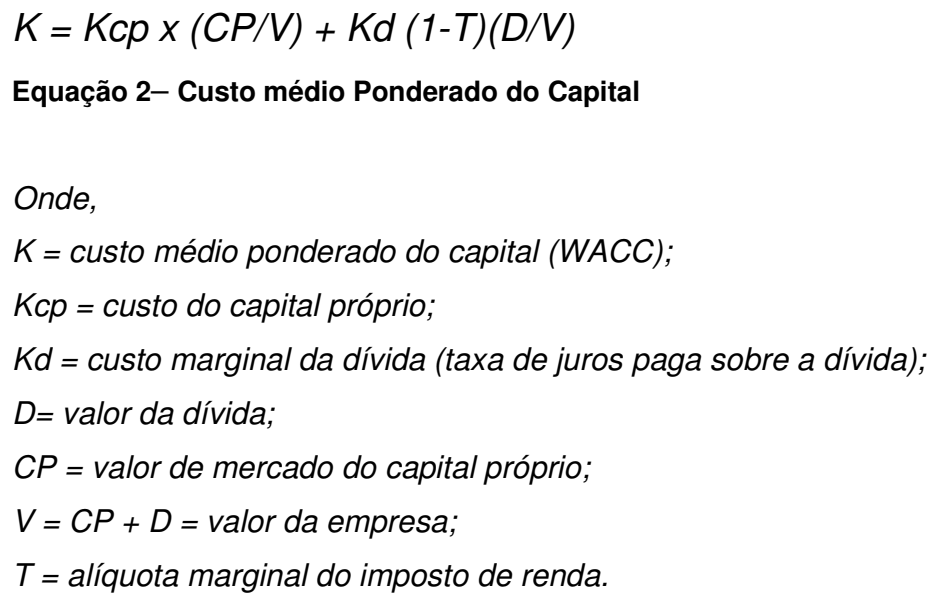

\subsubsection{CAPM}

O CAPM (Capital Asset Pricing Model) representa o retorno que os investidores de capital próprio exigem sobre seu investimento na empresa.

O CAPM avalia o retorno mínimo que um ativo deve oferecer ao investidor, em função do nível de risco não diversificável (ou sistemático) a ele associado. Tendo como premissa a aversão ao risco, o modelo pressupõe que ativos com maior nível de risco tenham que oferecer maior retorno, de forma a serem atrativos para os investidores (Ross, 2013). 
A fórmula é:

$R=R f+\beta \times(R m-R f)$

Equação 3- Custo do capital próprio

Onde:

$R=$ Retorno esperado do ativo $=K c p$;

$R f=$ Taxa de retorno livre de risco, ativo livre de risco;

$B=$ beta;

$R m$ = taxa esperada de retorno do portfolio de Mercado;

$R m-R f=$ Prêmio pelo risco do mercado, isto é, prêmio do risco para investir em renda variável.

Conforme Damodaran (2012), as conceituações dessas variáveis podem ser entendidas como: a taxa livre de risco são títulos públicos federais sem risco; o prêmio de risco é o prêmio que os investidores exigem para investirem no ativo do projeto ao invés de títulos mobiliários livre de risco e o beta é o coeficiente que quantifica o risco sistemático de um determinado ativo em relação a um ativo médio. Segundo Ross (2013) o risco sistemático significa um risco que influencia um número grande de ativos, são acontecimentos não previstos que, de alguma forma, interferem em quase todos os ativos, ou seja, o risco de mercado, sendo assim, o beta avalia o risco do projeto em comparação com o mercado, utilizando a medida da covariância dos retornos do ativo em relação aos retornos do mercado.

No geral, Ross (2013) identifica que no modelo CAPM, o retorno esperado é dependente das seguintes questões:

1) Puro valor do dinheiro no tempo: medido pela taxa livre de risco, que é a recompensa por esperar pelo retorno do seu dinheiro sem assumir risco algum;

2) O prêmio por assumir o risco sistemático: medido pelo prêmio de risco, corresponde ao prêmio que o mercado oferece por assumir o risco sistemático;

3) Quantidade de risco sistemático: medida pelo beta. A carteira representativa do mercado possui beta igual a 1 , ou seja, quando um ativo possui o valor maior que 1 significa que possui maior volatilidade possuindo maior risco comparado ao mercado. 


\subsection{Valor Presente Líquido}

O Valor presente líquido (VPL) é o somatório dos fluxos de caixas descontados a uma taxa em um período de tempo menos o seu investimento inicial, representando a diferença entre o valor de mercado de um investimento e seu custo (Ross, 2013). O método que utiliza o VPL tem como objetivo atribuir valor, em termos de valor presente, o impacto dos eventos futuros associados ao projeto (Samanez, 2002).

$$
V P L=-I+\sum_{t=1}^{n} \frac{F C_{t}}{(1+j)^{t}}
$$

Equação 4- Método do Valor Presente Líquido

Onde:

I = Investimento Inicial;

$J=$ Custo do capital;

$\Sigma F C t=$ somatório do fluxo de caixa.

Quando o VPL for maior que zero entende-se que é economicamente viável, logo o objetivo do VPL é definir projetos de investimento que valham mais para os acionistas do que custam. Assim, conforme Ross (2013), o VPL é uma forma de avaliar a lucratividade de um investimento.

\subsection{Taxa Interna de Retorno}

A TIR, taxa interna de retorno é a taxa de retorno esperada do projeto investido, ou seja, é a taxa intrínseca de rendimento. Segundo Samanez (2002) o método tem como finalidade a avaliação da rentabilidade a um determinado custo de capital.

A utilização da TIR, porém, segundo Ross (2013), pode apresentar problemas quando o fluxo de caixa não for convencional. Nesse caso, o fluxo de caixa operacional apresenta mais de uma inversão de sinal, obtendo taxas de retorno múltiplas. Assim, para atender essa situação, usa-se a TIR modificada, a qual retorna a taxa interna de retorno para uma série de fluxos de caixa periódicos, considerando o custo de investimento e os juros de reinvestimento de caixa. 


\subsection{Payback}

O payback é determinado como o tempo necessário para que o acionista seja reembolsado. Pode ser considerado o momento em que o fluxo de caixa acumulado torna-se positivo. Este, porém, apresenta falhas, pois ignora o valor do dinheiro no tempo, sendo assim utiliza-se o payback descontado, o qual é o período até que a soma dos fluxos de caixa descontados seja igual ao investimento inicial.

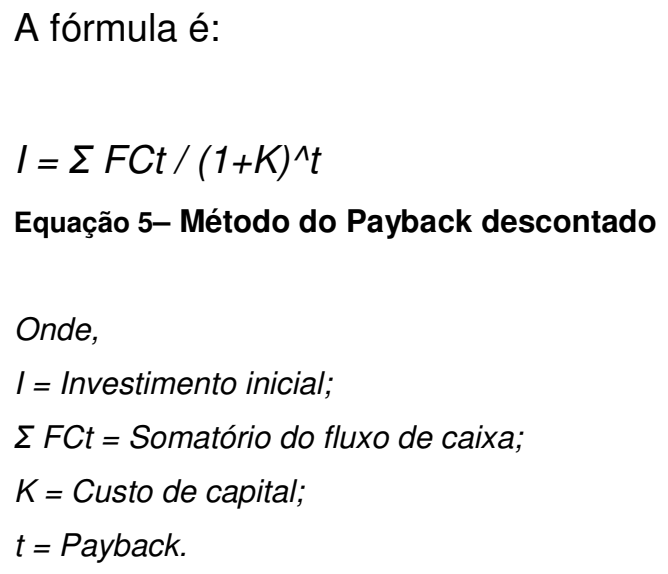

Para avaliar a aceitação do projeto, a empresa pode estipular um tempo para o payback, caso o período de payback for menor que o prazo limite, o projeto, para aquele contexto, é viável. 


\section{Estudo de Caso}

O presente trabalho irá tratar a viabilidade de um empreendimento residencial de baixa renda, participante do PMCMV. Após análise do mercado e dos fatores macroeconômicos, o público alvo do empreendimento selecionado serão os beneficiários que compõem a faixa 2 e 3, ou seja, usuários que podem adquirir um imóvel de até $\mathrm{R} \$ 190.000,00$.

A incorporadora imobiliária constituiu uma SPE para empreendimento em questão, podendo assim, realizar transações seguranças garantindo os direitos dos envolvidos como as obrigações entre ela e a construtora, descritas no contrato assinado. O nome proposto foi Ipê Empreendimentos Imobiliários Ltda.

\subsection{Características do empreendimento}

A escolha do terreno é fundamental para o estudo de viabilidade de um projeto imobiliário, pois além do alto valor de mercado existem diversas questões judiciais e construtivas que devem ser analisadas.

O terreno corresponde ao investimento inicial de um empreendimento e dependendo do seu valor, pode inviabilizar o projeto. Antes da compra é necessário realizar estudos mercadológicos sobre o produto para determinada região, pois nesse momento define-se o público alvo e o padrão que será adotado. O padrão do projeto estabelece o processo construtivo e os materiais que serão utilizados na construção, tal fator impacta diretamente no orçamento da obra (Vilela, 2011). Conforme Goldman (2015) é nesse momento que se forma o escopo do produto e se estima os meios e risco para a produção.

Além do valor, conforme o Ministério das Cidades, as construtoras devem se preocupar com os problemas judiciais que o terreno pode ter, como a dificuldade na regularização ou a presença de inventário que demanda tempo para solucionar.

Passando por essa análise, o terreno foi selecionado e está localizado no bairro de Jacarepaguá, na divisa da Barra da Tijuca, o qual possui 53.700 metros quadrados. O projeto foi desenvolvido de acordo com a legislação local e com base nos requisitos exigidos para os participantes do PMCMV. 
O empreendimento, construído pela construtora "Lazer", consiste em um conjunto residencial formado por nove torres com 14 pavimentos, totalizando 1.410 apartamentos de 2 quartos e em média 52 metros quadrados. O condomínio possui uma ampla área de lazer composta por piscina, quadra de esporte, playground, salão de festas, entre outros.

Por buscar atender os beneficiários com renda entre 5 e 10 salários, as unidades terão o preço de venda de $R \$ 130.037,50$ (cento e trinta mil trinta e sete reais e cinquenta centavos), atingindo o VGV (valor geral de venda) de $R \$$ 183.352.875,00 (cento e oitenta e três milhões e trezentos e cinquenta e dois mil e oitocentos e setenta e cinco reais). O VGV representa a soma do valor potencial de venda de todas as unidades de um empreendimento (FGV, 2015). Para a compra do terreno, foram permutadas 88 unidades e o pagamento do montante restante em dinheiro, ou seja, o VGV permutado foi de $R \$$ 11.443.300,00 (onze milhões quatrocentos e quarenta e três mil e trezentos reais) acrescidos de $R \$ 5.520 .000$ (cinco milhões e quinhentos e vinte mil reais) como investimento inicial.

\subsection{Orçamento}

O orçamento da obra é o suporte para a Engenharia de Custos, pois fornece o custo global da obra. É realizado pela construtora contratada, orientando as tomadas de decisões a serem feitas em relação ao cumprimento dos custos e prazos, e consequentemente a viabilidade do negócio (Vilela, 2011).

O orçamento do empreendimento foi realizado conforme modelo utilizado pela Caixa Econômica. A planilha foi elaborada de acordo com o levantamento quantitativo com base nos projetos de arquitetura e os preços unitários de mercado de cada material ou serviço.

Ainda prevê uma taxa de administração e manutenção que a construtora receberá conforme cronograma. A taxa de administração refere aos serviços prestados pela construtora, ou seja, é o recebível da construtora, já a taxa de manutenção é uma quantia paga à construtora para realizar a manutenção pósconclusão de obra, caso necessário.

O Ipê foi orçado em $\mathrm{R} \$ 97.256 .773,35$ (noventa e sete milhões duzentos e cinquenta e seis mil e setecentos e setenta e três reais e trinta e cinco centavos). Considerando o custo raso de $R \$ 86.558 .528,00$ (oitenta e seis milhões quinhentos e cinquenta e oito mil quinhentos e vinte oito reais), $10 \%$ de taxa de 
administração, equivalentes a $R \$ 9.725 .677,34$ (nove milhões setecentos e vinte e cinco mil seiscentos e setenta e sete mil reais e trinta e quatro centavos) e $1 \%$

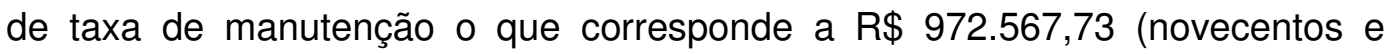
setenta e dois mil quinhentos e sessenta e sete reais e setenta e três centavos).

A taxa de administração representa o valor pago à construtora pela execução da obra e a taxa de manutenção também é paga para a construtora, porém esse valor tem por finalidade realizar a manutenção da obra durante cinco anos, caso necessário.

\subsection{Cronograma Físico-Financeiro da Obra}

Segundo Dias (2004), o cronograma físico-financeiro é a representação gráfica do planejamento da obra e deve conter todas as fases de execução. É fundamental realizá-lo, pois organiza de maneira temporal e financeira a obra, formando períodos, de maneira que o engenheiro possa acompanhar as atividades em paralelo com os custos.

Além de ferramenta para controle da construtora, é utilizado pela Caixa para planejar e realizar os desembolsos do financiamento. Por esse motivo que a obra também é acompanhada mensalmente pelo banco, pois apesar de previsto, o valor a ser desembolsado será de acordo com a execução de obra.

O cronograma também pode ser representado pela curva física e financeira da obra, a qual demonstra apenas a porcentagem total que deve ser executada em um determinado mês, conforme a tabela a seguir:

Tabela 1 - Cronograma físico-financeiro

\begin{tabular}{|c|c|c|}
\hline Mês & Curva financeira & Curva física \\
\hline $\mathbf{1 2}$ & 972.568 & $1,0 \%$ \\
\hline $\mathbf{1 3}$ & 972.568 & $1,0 \%$ \\
\hline $\mathbf{1 4}$ & 1.945 .135 & $2,0 \%$ \\
\hline $\mathbf{1 5}$ & 1.945 .135 & $2,0 \%$ \\
\hline $\mathbf{1 6}$ & 2.917 .703 & $3,0 \%$ \\
\hline $\mathbf{1 7}$ & 2.917 .703 & $3,0 \%$ \\
\hline $\mathbf{1 8}$ & 3.890 .271 & $4,0 \%$ \\
\hline $\mathbf{1 9}$ & 5.835 .406 & $6,0 \%$ \\
\hline $\mathbf{2 0}$ & 5.835 .406 & $6,0 \%$ \\
\hline $\mathbf{2 1}$ & 5.835 .406 & $6,0 \%$ \\
\hline $\mathbf{2 2}$ & 5.835 .406 & $6,0 \%$ \\
\hline $\mathbf{2 3}$ & 5.835 .406 & $6,0 \%$ \\
\hline
\end{tabular}

\begin{tabular}{|c|c|}
\hline $\begin{array}{c}\text { Curva financeira } \\
\text { Acumulada }\end{array}$ & $\begin{array}{c}\text { Curva física } \\
\text { Acumulada }\end{array}$ \\
\hline 972.568 & $1,0 \%$ \\
\hline 1.945 .135 & $2,0 \%$ \\
\hline 3.890 .271 & $4,0 \%$ \\
\hline 5.835 .406 & $6,0 \%$ \\
\hline 8.753 .110 & $9,0 \%$ \\
\hline 11.670 .813 & $12,0 \%$ \\
\hline 15.561 .084 & $16,0 \%$ \\
\hline 21.396 .490 & $22,0 \%$ \\
\hline 27.231 .897 & $28,0 \%$ \\
\hline 33.067 .303 & $34,0 \%$ \\
\hline 38.902 .709 & $40,0 \%$ \\
\hline 44.738 .116 & $46,0 \%$ \\
\hline
\end{tabular}




\begin{tabular}{|l|c|l|}
\hline $\mathbf{2 4}$ & 6.807 .974 & $7,0 \%$ \\
\hline $\mathbf{2 5}$ & 6.807 .974 & $7,0 \%$ \\
\hline $\mathbf{2 6}$ & 5.835 .406 & $6,0 \%$ \\
\hline $\mathbf{2 7}$ & 5.835 .406 & $6,0 \%$ \\
\hline $\mathbf{2 8}$ & 5.835 .406 & $6,0 \%$ \\
\hline $\mathbf{2 9}$ & 4.862 .839 & $5,0 \%$ \\
\hline $\mathbf{3 0}$ & 4.862 .839 & $5,0 \%$ \\
\hline $\mathbf{3 1}$ & 4.862 .839 & $5,0 \%$ \\
\hline $\mathbf{3 2}$ & 2.917 .703 & $3,0 \%$ \\
\hline $\mathbf{3 3}$ & 1.945 .135 & $2,0 \%$ \\
\hline $\mathbf{3 4}$ & 972.568 & $1,0 \%$ \\
\hline $\mathbf{3 5}$ & 972.568 & $1,0 \%$ \\
\hline
\end{tabular}

\begin{tabular}{|l|l|}
\hline 51.546 .090 & $53,0 \%$ \\
\hline 58.354 .064 & $60,0 \%$ \\
\hline 64.189 .470 & $66,0 \%$ \\
\hline 70.024 .877 & $72,0 \%$ \\
\hline 75.860 .283 & $78,0 \%$ \\
\hline 80.723 .122 & $83,0 \%$ \\
\hline 85.585 .961 & $88,0 \%$ \\
\hline 90.448 .799 & $93,0 \%$ \\
\hline 93.366 .502 & $96,0 \%$ \\
\hline 95.311 .638 & $98,0 \%$ \\
\hline 96.284 .206 & $99,0 \%$ \\
\hline 97.256 .773 & $100,0 \%$ \\
\hline
\end{tabular}

\subsection{Financiamento}

Após a conclusão das etapas anteriores, a incorporadora assinará o Contrato de Financiamento à Produção. A instituição financeira adotada foi a Caixa Federal Econômica.

- Valor do financiamento: é o valor efetivamente emprestado pela a instituição financeira. No caso, foi acordado $80 \%$ do custo de construção de obra, o que corresponde a $R \$ 77.805 .418,68$;

- Requisito: 30 \% de comercialização das unidades;

- Taxa: taxa de 8,00\% a.a. + T.R. em cima das liberações de recursos conforme as etapas executadas da obra, sendo que durante a obra apenas haverá o pagamento dos juros e atualização monetária;

- Garantia: fiança dos sócios da construtora incorporadora, hipoteca das unidades habitacionais;

- Prazos: pagamento até 24 meses após conclusão da obra.

Sendo assim, a partir das características (tabela 1) do financiamento, pode-se concluir que a liberação do banco ocorrerá de acordo com a tabela 2:

\section{Tabela 2 - Características do financiamento}

\begin{tabular}{|c|c|}
\hline Custo da obra & $97.256 .773,35$ \\
\hline Financiamento & $80 \%$ \\
\hline Valor do financiamento & $77.805 .418,68$ \\
\hline
\end{tabular}


Tabela 3 - Fluxo de desembolso para o financiamento da obra

\begin{tabular}{|c|c|c|}
\hline Mês & Curva física & $\begin{array}{c}\text { Liberação } \\
\text { Financiamento }\end{array}$ \\
\hline 12 & $1,0 \%$ & 778.054 \\
\hline 13 & $1,0 \%$ & 778.054 \\
\hline 14 & $2,0 \%$ & 1.556 .108 \\
\hline 15 & $2,0 \%$ & 1.556 .108 \\
\hline 16 & $3,0 \%$ & 2.334 .163 \\
\hline 17 & $3,0 \%$ & 2.334 .163 \\
\hline 18 & $4,0 \%$ & 3.112 .217 \\
\hline 19 & $6,0 \%$ & 4.668 .325 \\
\hline 20 & $6,0 \%$ & 4.668 .325 \\
\hline 21 & $6,0 \%$ & 4.668 .325 \\
\hline 22 & $6,0 \%$ & 4.668 .325 \\
\hline 23 & $6,0 \%$ & 4.668 .325 \\
\hline 24 & $7,0 \%$ & 5.446 .379 \\
\hline 25 & $7,0 \%$ & 5.446 .379 \\
\hline 26 & $6,0 \%$ & 4.668 .325 \\
\hline 27 & $6,0 \%$ & 4.668 .325 \\
\hline 28 & $6,0 \%$ & 4.668 .325 \\
\hline 29 & $5,0 \%$ & 3.890 .271 \\
\hline 30 & $5,0 \%$ & 3.890 .271 \\
\hline 31 & $5,0 \%$ & 3.890 .271 \\
\hline 32 & $3,0 \%$ & 2.334 .163 \\
\hline 33 & $2,0 \%$ & 1.556 .108 \\
\hline 34 & $1,0 \%$ & 778.054 \\
\hline 35 & $1,0 \%$ & 778.054 \\
\hline
\end{tabular}

\subsection{Fluxo de Caixa}

Para um melhor entendimento de como será o funcionamento do fluxo de caixa, ou seja, de como serão as entradas e saídas ao longo do tempo, foi feito uma análise do ciclo da SPE, a qual pode ser exemplificada na figura 5. 


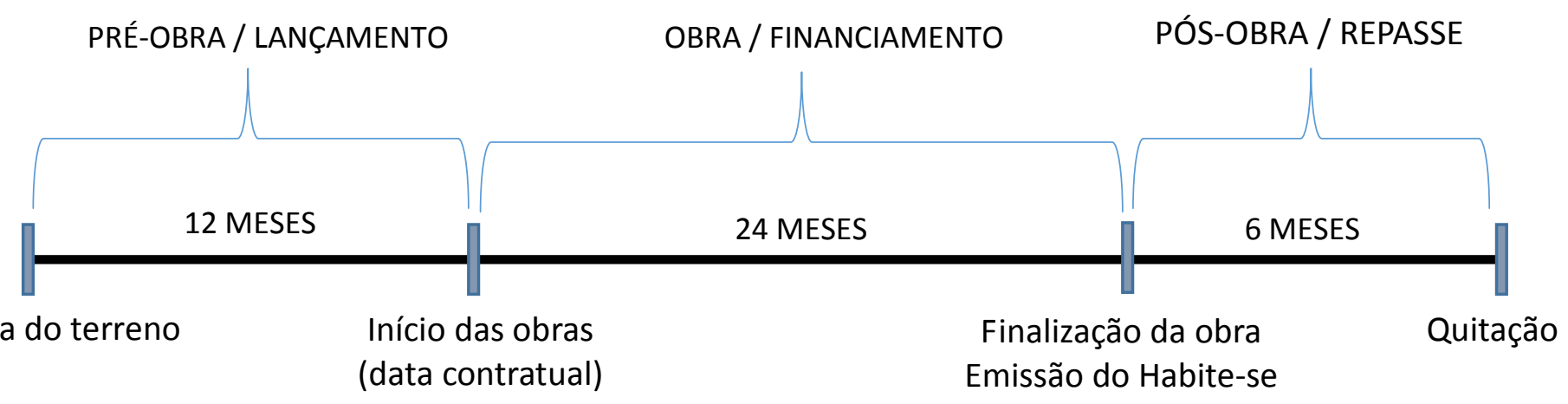

Figura 5: Ciclo de vida da SPE.

Fonte: Própria; dados da construtora.

Como exemplificado na imagem anterior, a vida de uma SPE é dividida em três períodos, sendo esses o pré-obra, obra e pós-obra. A compra do terreno ocorre após definição do produto e estudo de viabilidade, sendo o ponto inicial para a criação da SPE. Registrada, com CNPJ e projeto legal aprovado na prefeitura, inicia-se o processo de desenvolvimento.

A primeira etapa, definida como Pré - Obra é marcada pelos primeiros gastos da SPE. Apesar de não possuir nenhum custo efetivo da obra, são despesas de extrema importância para o desenvolvimento e sucesso do projeto.

Durante esse período há despesas com marketing e corretagem para a fase de lançamento das unidades, o que significa um grande investimento para garantir destaque no mercado e captação dos clientes, visando o maior número de entradas em forma de receita e os $30 \%$ de unidades comercializadas. Afinal esse fator é requisito para o financiamento da obra, o qual também é negociado durante esse período.

$\mathrm{Na}$ área de construção, segundo Vilela (2011) há uma grande preocupação em elaborar o planejamento (cronograma físico - financeiro) e orçamento (custo de obra) para que esses tenham aderência na fase de obra, sendo assim, é necessário criar projetos executivos que detalhem realmente como será feito. O autor afirma ainda que é fundamental realizar um exame sobre o terreno, para que, imprevistos com a fundação sejam reduzidos.

Normalmente essa primeira etapa não possui um tempo estipulado, pois é determinada de acordo com a estratégia adotada pelos acionistas, diante da vulnerabilidade do setor. A partir dessa data em 1 ano, em média, inicia-se a construção.

Com a assinatura do contrato de construção entre a SPE e construtora, fica estipulado à data de início das obras e o início da segunda etapa. Essa data 
será a mesma acordada com o banco, a Caixa Federal Econômica, para que possa realizar as medições e iniciar a liberação do empréstimo.

Essa fase possui o prazo de 24 meses, por dois motivos:

- Atender o prazo alinhado com o banco para a construção da obra e início da amortização do saldo devedor;

- Atender o prazo contratual com os clientes para entrega das unidades, caso o contrário será necessário o pagamento de multas.

Quando a obra é concluída e passa para a última etapa, deve-se emitir o habite-se (documento fornecido pela prefeitura indicando que o projeto está pronto para ser habitado e que seguiu todas as exigências legais), ponto essencial para o repasse e quitação da dívida com a Caixa. O repasse é caracterizado pelo momento que o cliente repassa seu saldo devedor com a construtora para uma instituição financeira, o qual é de extrema importância para a construtora, pois consegue quitar seu financiamento com o banco.

Com a contextualização do ciclo de um empreendimento imobiliário, pode-se definir as receitas e despesas para o fluxo de caixa.

A receita é à entrada de capital em um projeto, no caso de empreendimentos imobiliários a entrada de capital é feita através da venda de unidades ou em aluguéis. Na SPE Ipê, essa é garantida pela venda dos apartamentos.

Conforme Goldman (2015), a estimativa das receitas das unidades é resultante do cálculo das áreas privativas pelos valores em reais do metro quadrado, permitindo o comparativo com os valores de mercado. A Associação de dirigentes de empresas do mercado imobiliário (ADEMI - RJ) dispõe relatórios mensais com os preços unitários do metro quadrado, de vendas dos lançamentos do Rio de Janeiro, por bairro, por finalidade do produto e por tipologia.

O bom desenvolvimento do negócio imobiliário é determinado pela questão temporal, o fluxo das receitas. A sensibilidade dos profissionais da área estipulam o início e término das ações a serem realizadas, buscando ter maior margem de lucratividade. É fundamental realizar ensaios de vendas das unidades para prevenir o momento de maior exposição do fluxo de caixa e buscar reduzir os aportes dos acionistas ao longo do projeto. (Goldman, 2015). Por esse motivo que as vendas das unidades começam a ser feitas antes do início da obra, no lançamento.

No caso estudado o valor da unidade foi determinado de acordo com as determinações a seguir: 
Tabela 4 - Valor das unidades

\begin{tabular}{|c|c|}
\hline Preço do $\mathrm{m}^{2}$ & $2.575,00$ \\
\hline Área privativa da unidade & 50,50 \\
\hline Preço da unidade & $130.037,50$ \\
\hline
\end{tabular}

Para o cálculo das projeções futuras do fluxo de caixa foram estabelecidas premissas para as receitas e despesas do projeto.

No modelo desenvolvido foi adotado a venda de unidades no tempo como a projeção das receitas. O fluxo dos recebíveis foi distribuído buscando uma maior margem de lucro e atendendo as exigências do programa de financiamento. Dessa maneira $30 \%$ das unidades foram previstas para a comercialização no lançamento, 50\% durante a obra, $15 \%$ na entrega das chaves e $5 \%$ foram consideradas como estoque, não tendo a entrada dessa receita, por enquanto, no fluxo de caixa.

Tabela 5 - Características do fluxo de receitas

\begin{tabular}{|l|r|r|}
\cline { 2 - 3 } \multicolumn{1}{c|}{} & \multicolumn{1}{c|}{ Valor } & \multicolumn{1}{c|}{ Unidades } \\
\hline VGV & $\mathrm{R} \$ 183.352 .875,00$ & 1410 \\
\hline VGV permutado & $\mathrm{R} \$ 11.443 .300,00$ & 88 \\
\hline VGV total & $\mathrm{R} \$ 171.909 .575,00$ & 1322 \\
\hline Lançamento & $\mathrm{R} \$ 51.572 .872,50$ & $30 \%$ VGV \\
\hline Meio-obras & $\mathrm{R} \$ 85.954 .787,50$ & $50 \%$ VGV \\
\hline Chaves & $\mathrm{R} \$ 25.786 .436,25$ & $15 \%$ VGV \\
\hline Estoque & $\mathrm{R} \$ 8.595 .478,75$ & $5 \%$ VGV \\
\hline
\end{tabular}

As parcelas das entradas foram divididas de acordo com o seu tipo de receitas, as quais representam a estratégia da incorporadora em relação à cobrança dos seus recebíveis. 
Tabela 6 - Fluxo de receitas

\begin{tabular}{|c|c|c|c|c|}
\hline \multirow[b]{2}{*}{ Mês } & \multicolumn{4}{|c|}{ Receitas } \\
\hline & Lançamento & $\begin{array}{c}\text { Meio } \\
\text { Obras }\end{array}$ & Chaves & Estoque \\
\hline $\begin{array}{l}0 \\
1\end{array}$ & & & & \\
\hline$\ldots$ & 2.475 & & & \\
\hline 7 & & & & \\
\hline 8 & & & & \\
\hline 9 & & & & \\
\hline 10 & & & & \\
\hline 11 & & & & \\
\hline 12 & 208 & 2.063 & & \\
\hline 13 & 209 & & & \\
\hline 14 & 211 & & & \\
\hline 15 & 211 & & & \\
\hline 16 & 212 & & & \\
\hline 17 & 213 & & & \\
\hline 18 & 215 & 1.410 & & \\
\hline 19 & 222 & 178 & & \\
\hline 20 & 222 & 178 & & \\
\hline 21 & 223 & 179 & & \\
\hline 22 & 224 & 179 & & \\
\hline 23 & 224 & 180 & & \\
\hline 24 & 225 & 1.162 & & \\
\hline 25 & 226 & 512 & & \\
\hline 26 & 226 & 513 & & \\
\hline 27 & 228 & 518 & & \\
\hline 28 & 229 & 519 & & \\
\hline 29 & 230 & 522 & & \\
\hline 30 & & 526 & & \\
\hline 31 & & 536 & & \\
\hline 32 & & 357 & & \\
\hline 33 & & 360 & & \\
\hline 34 & & 361 & & \\
\hline 35 & & 361 & & \\
\hline 36 & 54.733 & 85.674 & 1.238 & \\
\hline 37 & & & & \\
\hline 38 & & & 24.670 & \\
\hline TOTAL & 61.169 & 96.288 & 25.908 & 8.595 \\
\hline
\end{tabular}

Valores em Milhares R $\$$

Após determinar o fluxo de recebíveis do fluxo de caixa, é possível projetar as despesas para atender todas as previsões de venda e custos para a construção do empreendimento. As despesas são todas as saídas do empreendimento, compreendidas como: compra do terreno (investimento inicial do empreendimento), incorporação (despesas com o registro do imóvel - RGI, licença de obra, consultoria jurídica, gastos com os clientes, entre outros), marketing, corretagem, imposto sobre a venda, projetos (despesas com todos os projetos de arquitetura do empreendimento), habite-se, custo obra, fundo 
especial mobiliário (despesas com o mobiliário do prédio residencial, decoração e iluminação).

Por fim, para se calcular a taxa de desconto será utilizado o modelo do WACC, através da fórmula do item 3.2.1., sendo necessário determinar o custo de capital próprio pelo método CAPM possível pela equação 4.

No modelo CAPM existe uma relação de equilíbrio entre o risco e o retorno esperado, o que significa que o investimento deve gerar um rendimento proporcional a seu risco.

O risco sistemático representa o risco que não pode ser evitado pela diversificação de ações, assim quanto maior for o $\beta$, maior será a rentabilidade exigida pelo investidor. Para calculá-lo, é preciso medir as variações do preço da ação em relação às flutuações do mercado de ações. Sendo assim é possível encontrar o beta em questão, através da média do risco sistemático de empresas do mesmo ramo que possuem capital aberto estando inscritas na bolsa de valores. Damodaram, especialista sobre assunto, criou uma base de dados contendo informações sobre o mercado, as quais estão disponíveis no $\begin{array}{ll}\text { site http://people.stern.nyu.edu/adamodar/New Home Page/data.html. } & 0\end{array}$ primeiro passo foi identificar a qual tipo de indústria o empreendimento está inserido, representado pelo "Homebuilding", já que esse grupo é composto por empresas do ramo da construção de projetos residenciais. Assim foi possível chegar ao beta desalavancado de 0,92.

Porém, como a empresa não possui apenas capital próprio, mas também dívidas como financiamento, esse deve ser alavancado pela seguinte fórmula:

$$
\text { Beta alavancado }=\beta^{*}\left[1+(1-T)^{*}(D / E)\right]
$$

Equação 6- Beta alavancado

Tabela 7 - Beta

\begin{tabular}{|c|c|c|c|}
\hline B setor & Debt / Equity (D/E) & Imposto (T) & $\begin{array}{c}\text { Beta alavancado } \\
\left(\mathrm{B}^{*}\left[1+(1-\mathrm{T})^{*}(\mathrm{D} / \mathrm{E})\right]\right.\end{array}$ \\
\hline 0,92 & $60,76 \%$ & $18,11 \%$ & 1,3708 \\
\hline
\end{tabular}

A taxa livre de risco pode ser extraída do site da Bloomberg. Para isso, a opção mais frequente a ser usada é o rendimento do tesouro americano (10-year T. Note) nos países que tem o dólar como referência de moeda internacional, 
pois apresenta baixa probabilidade de inadimplência, ou seja, é um rendimento seguro, no qual o investidor garante seu retorno. Devido as grandes mudanças no mercado imobiliário nos últimos anos, a série histórica adotada foi desde o início de 2014 até hoje e a média de retorno do título nesse período foi de $2,38 \%$ :

\section{Tabela 8 - Média de rentabilidade dos títulos públicos}

\begin{tabular}{|c|c|}
\hline $\begin{array}{c}\text { Série histórica } \\
\text { adotada }\end{array}$ & $\begin{array}{c}10 \text {-year T. Note } \\
\text { (média) }\end{array}$ \\
\hline 2014 - até hoje & $2,38 \%$ \\
\hline
\end{tabular}

O prêmio de risco representa a diferença entre o retorno de mercado e a taxa livre de risco, ou seja, é a diferença entre os ativos expostos no mercado pelos títulos governamentais livres de risco. Como parâmetro foi utilizado também o site da Bloomberg sendo a diferença entre o S\&P 500 pelo T-Note, referenciando o mesmo período de tempo, encontrando o valor de $4,38 \%$ :

\section{Tabela 9 - Prêmio de risco}

\begin{tabular}{|c|c|}
\hline $\begin{array}{c}\text { Período } \\
\text { adotado }\end{array}$ & $\begin{array}{c}\text { Prêmio de Risco } \\
\text { Stocks - T.Bonds }\end{array}$ \\
\hline 2014 - até hoje & $4,38 \%$ \\
\hline
\end{tabular}

Até então, todos os valores foram extraídos da base de dados de Demodaram e do site da Bloomnerg, representado pelo mercado internacional. Nesse contexto faz sentido incluir o risco país do Brasil, pois informa o risco de crédito a que os investidores estrangeiros estão submetidos quando investem no país. (Banco Central do Brasil, 2015).

No mercado, os indicadores diários utilizados para essa finalidade são o Emerging Markets Bond Index Plus (EMBI+) e o Credit Default Swap (CDS). No estudo de caso será utilizado o $\mathrm{EMBI}+$, que é o índice ponderado que mede 0 retorno de instrumentos de dívida externa de mercados emergentes ativamente negociados. No caso do Brasil,o EMBI+ $\mathrm{Br}$ representa o comportamento dos títulos da dívida externa brasileira, sendo a capacidade do país honrar com seus 
compromissos financeiros. (BCB, 2015). Para isso, dar-se o nome de spread do $\mathrm{EMBI}+\mathrm{Br}$ ao valor utilizado pelos investidores como medida do risco-Brasil, o qual corresponde à média ponderada dos prêmios pagos por esses títulos em relação aos papéis de prazo semelhante do tesouro americano. Logo, quanto maior for à pontuação do indicador de risco, maior será o risco do país.

O valor do $\mathrm{EMBI}+\mathrm{Br}$, pode ser encontrado no site http://www.ipeadata.gov.br/ExibeSerie.aspx?serid=40940\&module=M. A série utilizada foi a mesma das variáveis anteriores de 2005 - 2014, resultando em uma taxa de 2,43.

A fórmula agora passa a ser:

$$
\begin{aligned}
& K e=R f+\beta \times(R m-R f)+\text { Risco Brasil + Risco Cambial } \\
& \text { Equação 7- Modelo CAPM + Risco Brasil + Risco Cambial }
\end{aligned}
$$

O Ke até agora está dimensionado em dólar, sendo necessário trazer o seu valor para o real. Essa transformação pode ser feita através do diferencial de inflação brasileiro com o americano. O índice brasileiro representado pelo Índice Nacional de Preços ao Consumidor (IPCA) pode ser encontrado no relatório de Mercado Focus emitido pelo Banco Central, a taxa é de 6,29\%. Já a inflação americana é informada pelo Federal Reserve (FED), banco central americano e a taxa projetada é de $2,13 \%$.

Por conclusão o custo de capital próprio é de $15,44 \%$ a.a. ou 1,20\% a.m., conforme detalhado a seguir:

\section{Tabela 10 - Tabela CAPM}

\begin{tabular}{lr}
\hline Rf: Taxa livre de risco & $2,38 \%$ \\
Risco Brasil (Z) & $2,43 \%$ \\
\hline (Rf+ Z) & $4,81 \%$ \\
\hline Beta do setor & 0,92 \\
D/E & $60,76 \%$ \\
Imposto & $18,11 \%$ \\
\hline Beta alavancado & $\mathbf{1 , 3 7}$ \\
\hline \hline (Rm - Rf): Prêmio de risco & $4,38 \%$ \\
\hline ( $*$ (Rm - Rf)) & $6,00 \%$ \\
\hline Ke em US\$ = Rf + $\beta$ x (Rm - Rf) + Z & $10,81 \%$ \\
Diferencial de Inflação (Brasil - EUA) & $4,17 \%$ \\
\hline
\end{tabular}


Como o PMCMV possui financiamento junto à Caixa Econômica Federal, apenas o custo de capital próprio não é determinante para a taxa de desconto, sendo necessário calcular o capital de terceiros, precisando assim utilizar 0 WACC. O custo da dívida é o retorno exigido pelos credores da empresa, sendo a taxa de juros paga sobre a dívida, logo o valor da dívida é o financiamento da construtora com o banco mais as taxas de juros de $8,00 \%$ ao ano + TR, totalizando o valor de $\mathrm{R} \$ 78.306 .021,09$ e o patrimônio da empresa é todo o valor restante necessário para cobrir as despesas do empreendimento, logo é de $\mathrm{R} \$ 56.780 .963,59$. A alíquota do imposto de renda é de $15 \%$ para o setor imobiliário. Com isso, a taxa de desconto calculada é de $11,36 \%$ a.a. ou $0,90 \%$ a.m.

Tabela 11 - Tabela WACC

\begin{tabular}{|c|c|}
\hline Ke & $15,44 \%$ \\
\hline \% de capital próprio (CP/V) & $42,51 \%$ \\
\hline $\mathrm{Ke}^{*}(\mathrm{CP} / \mathrm{V})$ & $6,56 \%$ \\
\hline Kd: taxa de juros paga sobre a dívida & $9,83 \%$ \\
\hline T: alíquota imposto de renda & $15,00 \%$ \\
\hline$\%$ de capital de terceiros & $57,97 \%$ \\
\hline$K d *(1-T) *(D / V)$ & $3,91 \%$ \\
\hline $\mathrm{Ke}+\mathrm{Kd}$ & $11,36 \%$ \\
\hline WACC & $\begin{array}{l}11,36 \% \text { a.a } \\
\text { 0,90\% a.m. }\end{array}$ \\
\hline
\end{tabular}

Com a determinação das premissas para o fluxo de caixa, esse pode ser apresentado de acordo com a tabela abaixo: 
Tabela 12 - Fluxo de Caixa

\begin{tabular}{|c|c|c|c|c|c|c|c|c|c|c|c|c|c|c|c|}
\hline Ano & 0 & 1 & 2 & $\ldots$ & 6 & 7 & $\cdots$ & 12 & 13 & $\cdots$ & 19 & 20 & $\ldots$ & 37 & 38 \\
\hline \multicolumn{16}{|l|}{ Receitas } \\
\hline Lançamento & & & & & 2.475 & & & 208 & 209 & & 222 & 222 & & & \\
\hline Meio Obras & & & & & & & & 2.063 & & & 178 & 178 & & & \\
\hline Chaves & & & & & & & & & & & & & & & 24.670 \\
\hline $\begin{array}{l}\text { Total das } \\
\text { receitas }\end{array}$ & & & & $\cdots$ & 2.475 & & $\ldots$ & 2.271 & 209 & $\cdots$ & 399 & 401 & $\cdots$ & & 24.670 \\
\hline \multicolumn{16}{|l|}{ Despesas } \\
\hline $\begin{array}{l}\text { Compra do } \\
\text { terreno }\end{array}$ & 5.520 & & & & & & & & & & & & & & \\
\hline Incorporação & & & 100 & & 80 & 80 & & 80 & 80 & & 80 & 80 & & 80 & 80 \\
\hline $\begin{array}{l}\text { Marketing / } \\
\text { Publicidade }\end{array}$ & & & & & 447 & 447 & & 247 & 247 & & 247 & 247 & & 447 & \\
\hline Corretagem & & & & & 149 & & & 136 & 13 & & 24 & 24 & & & 1.480 \\
\hline $\begin{array}{l}\text { Imposto sobre } \\
\text { venda }\end{array}$ & & & & & 90 & & & 83 & 8 & & 15 & 15 & & & 900 \\
\hline Projetos & & 350 & 150 & & 100 & 65 & & 65 & 65 & & & & & & \\
\hline Habite-se & & & & & & & & & & & & & & & 10 \\
\hline Custo de Obra & & & & & & & & 973 & 973 & & 5.835 & 5.835 & & & \\
\hline FME & & & & & & & & & & & & & & 150 & \\
\hline $\begin{array}{l}\text { Total das } \\
\text { despesas }\end{array}$ & 5.520 & 350 & 250 & $\cdots$ & 866 & 592 & $\ldots$ & 1.584 & 1.385 & $\cdots$ & 6.201 & 6.201 & $\cdots$ & 677 & 2.471 \\
\hline Saldo & 5.520 & 350 & 250 & $\ldots$ & 1.610 & 592 & $\ldots$ & 688 & 1.175 & $\ldots$ & 5.802 & 5.800 & $\ldots$ & 677 & 22.199 \\
\hline \multicolumn{16}{|l|}{ Financiamento } \\
\hline Liberação & & & & & & & & & & & 12.449 & 4.668 & & & \\
\hline Juros & & & & & & & & & & & & 98 & & 6 & \\
\hline Repasse & & & & & & & & & & & & & & 77.805 & \\
\hline $\begin{array}{l}\text { Total fluxo } \\
\text { financiamento }\end{array}$ & & & & & & & & & & & 12.449 & 4.571 & & 77.812 & \\
\hline $\begin{array}{l}\text { Lucro } \\
\text { operacional }\end{array}$ & 5.520 & 350 & 250 & $\cdots$ & 1.610 & 592 & $\ldots$ & 688 & 1.175 & $\cdots$ & 6.647 & 1.229 & $\cdots$ & 78.488 & 22.199 \\
\hline IR & & & 73 & & & & & & & & & 32 & & & 861 \\
\hline CSLL & & & 66 & & & & & & & & & 29 & & & 775 \\
\hline Fluxo Livre & 5.520 & 350 & 390 & ... & 1.610 & 592 & ... & 688 & 1.175 & $\ldots$ & 6.647 & 1.290 & $\ldots$ & -78.488 & 20.563 \\
\hline Acumulado & 5.520 & 5.870 & 6.260 & & 5.465 & 6.057 & & 7.786 & 8.962 & & 15.642 & 16.932 & & 24.787 & 45.349 \\
\hline Descontado & 5.520 & 347 & 383 & & 1.525 & 556 & & 618 & 1.046 & & 5.606 & 1.078 & & 56.321 & 14.623 \\
\hline $\begin{array}{l}\text { Descontado } \\
\text { Acumulado }\end{array}$ & 5.520 & 5.867 & 6.249 & & 5.507 & 6.063 & & 7.665 & 8.771 & & 14.634 & 15.713 & & 14.343 & 28.966 \\
\hline VPL & 28.966 & & & & & & & & & & & & & & \\
\hline TIRM & $1,66 \%$ & & & & & & & & & & & & & & \\
\hline Payback & $36^{\circ}$ mês & & & & & & & & & & & & & & \\
\hline
\end{tabular}




\subsection{Análise dos resultados}

O modelo de viabilidade econômica através do fluxo de caixa descontado proposto alcançou um resultado de $\mathrm{R} \$ 28.965 .795,98$ representando o valor presente líquido, ou seja, o quanto de valor foi adicionado, hoje, realizando esse investimento.

A TIR, por sua vez, representa a taxa de rentabilidade devida ao investimento do projeto. No fluxo de caixa apresentado anteriormente, a TIR seria de 4,45\% a.m., porém, por se tratar de um fluxo de caixa não convencional, ou seja, durante a projeção do fluxo o VPL se apresenta de forma inconstante variando entre valores negativos e positivos, foi necessário calcular a TIR modificada, encontrando o valor de 1,66\% a.m.

Sendo assim, o projeto residencial é considerado viável, pois ambos os resultados da metodologia foram favoráveis, já que o VPL possui valor positivo assim como a TIR excedeu a taxa de desconto que era de 0,90\% a.m.

Apesar do cálculo da taxa de desconto, a construtora em questão, utiliza em seus empreendimentos uma taxa histórica de $10 \%$ a.a. ou $0,8 \%$ a.m. Dessa maneira, fez-se necessário um estudo comparativo entre taxas para compreender as diferenças encontradas nos resultados e no que isso pode impactar.

A ideia é utilizar as mesmas premissas do fluxo de caixa analisado anteriormente, porém o descontando de diferentes taxas, podendo averiguar o impacto do VPL. Caso este seja muito sensível às variações, então há um risco associado a esta variável.

A partir do gráfico da figura 6 , as comparações realizadas a diferentes taxas de desconto apresentaram variações consideráveis no VPL, determinando a importância do cálculo da taxa de desconto no fluxo de caixa. 


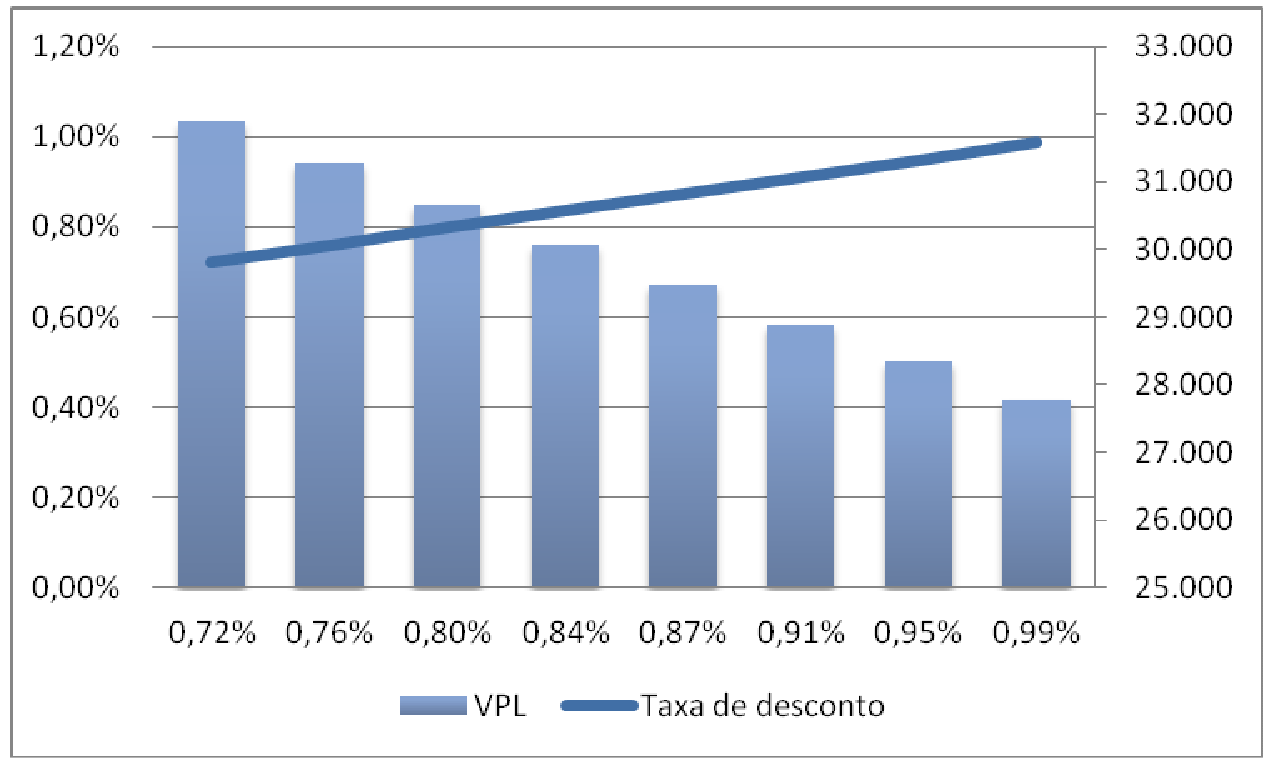

Figura 6: Análise do VPL x TIR.

Fonte: Própria.

O VPL decresce à medida que a taxa de desconto aumenta, ou seja, as variáveis são inversamente proporcionais o que significa que, quanto maior for à taxa de desconto, maior será a exigência do retorno, pois maior será o risco de mercado, obtendo um menor valor presente líquido.

Assim, conclui-se que o melhor para a construtora seria calcular a taxa de desconto, pois o resultado pode não atender as exigências dos acionistas. No caso analisado à diferença entre o VPL foi de $R \$ 28.965 .795,98$ para $R \$$ 30.570.292,43 (VPL da construtora), logo a sua viabilidade econômico-financeira apresenta uma distorção nos resultados, pois houve uma diferença de $R \$$ 1.604.496,45 no VPL o que poderia prejudicar a tomada de decisão. 


\section{Conclusão}

O Programa Minha Casa, Minha Vida vem apresentando resultados positivos no cenário brasileiro, cooperando na redução do déficit habitacional. Tal fato comprova a importância do desenvolvimento de projetos habitacionais voltados para baixa renda, que representam uma alta demanda no mercado do país.

A maior preocupação, até então, era viabilizar a dinâmica desse tipo de empreendimento, a qual foi confirmada com a elaboração do fluxo de caixa e análise dos seus resultados. O referencial teórico e a metodologia apresentados ajudaram na compreensão de uma incorporadora imobiliária e na determinação das premissas necessárias e adequadas ao projeto. A grande contribuição do empreendimento, por ser participante do PMCMV, pode ser compreendida pelos parâmetros favoráveis para a elaboração do fluxo de caixa, diante do financiamento diferenciado e o cálculo da taxa de desconto, que resultaram em um VPL (maior que zero) e TIR (maior que a taxa de desconto) viáveis.

A determinação da taxa de desconto mostrou a sua importância para o estudo de viabilidade, pois caso esta não seja calculada de acordo com o mercado, não estará proporcionando o grau de risco devido para exigência dos acionistas, tendo um valor presente líquido distorcido da sua realidade.

Logo, o empreendimento participante da modalidade do Programa Minha Casa, Minha Vida, não só obtém um resultado econômico-financeiro positivo para as incorporações, como também, por consequência, traz benefícios para toda a sociedade por aquecer o mercado imobiliário e da construção civil. A realização de infraestrutura adequada, a realização de moradias que atendam às demandas, a geração de empregos diretos e indiretos acabam favorecendo a sustentabilidade social. 


\subsection{Sugestões e recomendações para novas pesquisas}

O payback do empreendimento em questão ocorreu no $37^{\circ}$ mês, momento em que os acionistas são reembolsados em relação ao investimento. Pela análise do fluxo de caixa, entende-se que é o período marcado pelo repasse, ou seja, quando a dívida dos clientes é repassada para a instituição financeira. Até então a entrada de recebíveis era composta pelas baixas parcelas acordadas com os consumidores para a compra de uma unidade. Sendo assim, faz sentindo analisar a possibilidade do repasse ocorrer em outro mês.

Nos últimos cinco anos esse cenário vem se modificando apresentando adaptações no mercado devido a busca das incorporadoras em obter melhores margens em seus lançamentos e uma gestão mais eficiente do caixa, através de alternativas para se livrar do devedor mais cedo. Com isso, alguns bancos começaram a atender a demanda antecipando o repasse (Cyrela, 2014).

As construtoras, então precisam determinar qual o melhor momento para viabilizar o repasse antecipado. Quando um imóvel é comprado na planta, durante o período financiado pela construtora, as parcelas e o saldo devedor são corrigidos mensalmente pelo Índice Nacional dos Custos da Construção (INCC). Ao mesmo tempo, a construtora paga os juros do financiamento que faz com o banco para erguer a obra. O cálculo que a empresa faz para o repasse antecipado é equilibrar as duas variáveis para acertar o momento ideal de transferir o devedor para o banco, ou seja, no momento em que são efetuados a venda da unidade e o repasse, o valor a ser desembolsado ao empreendedor passa a ser congelado, não havendo reajuste. Dessa forma, A SPE fica mais desprotegida em relação às variações nos custos dos insumos e no custo da mão de obra durante a fase de construção. Por isso, que a escolha do tempo de repasse é de extrema importância para o empreendimento, pois pode ser considerada uma estratégia financeira para viabilizar o fluxo de caixa.

Segundo o Banco do Brasil, os empreendimentos financiados com recursos do FGTS, como o PMCMV, já podem realizar o repasse antecipado, podendo ter início desde a venda na planta e, agora, não somente na entrega do empreendimento. Com isso, além de receber a parcela referente a liberação do financiamento do custo de construção, a SPE passa a arrecadar durante a fase de produção o lucro do empreendimento. 


\section{Bibliografia}

ABECIP:http://www.abecip.org.br/m22.asp?cod pagina=680\&submenu=sim\&cod pai $=4$ $\underline{30}$ e <http://www.abecip.org.br/imagens/palestra teotonio final.pdf $>$ : acesso em maio 2015.

BANCO CENTRAL; <http://www.bcb.gov.br/pt-br/paginas/default. aspx>: acesso em abril 2015.

BOSCARDIN: Ivan Mercadante. "Artigos Jurídicos sobre Direito Imobiliário".

BRAGA, Roberto. Fundamentos e técnicas de administração financeira. $4^{a}$ edição. São Paulo: Atlas, 1995.

http://mercadanteadvocacia.com/artigos/\#, acesso em maio 2015.

BUENO, P. et AL. As transformações do mercado imobiliário brasileiro nos anos 2000 - uma análise do ponto de vista legal e econômico. Congresso Internacional de Administração, p.11, 2012.

CAIXA ECONÔMICA FEDERAL: http://www.caixa.gov.br/Paginas/home-caixa.aspx: acesso em abril 2015.

http://www.caixa.gov.br/empresa/credito-financiamento/imoveis/financiamento-para-

producao-imoveis/plano-empresa-da-construcao-civil/Paginas/default.aspx: acesso abril 2015.

CÂMERA BRASILEIRA DA INDÚSTRIA DA CONSTRUÇÃO; http://www.cbic.org.br/: acesso em fevereiro e abril 2015.

DANTZGER, Afrânio Carlos Camargo. Alienação fiduciária de bens imóveis. São Paulo: Método, 2005.

DIAS, P. R. V. Engenharia de custos: Uma metodologia para orçamentação de obras civis. Copiare, 5a edição, 2004.

EZTEC:

http://ri.eztec.com.br/eztec2009/web/conteudo pt.asp?idioma=0\&conta=28\&tipo=26848: acesso em fevereiro 2015.

FRANCO, J. Nascimento; GONDO, Nisske. Incorporações Imobiliárias. Revistas dos Tribunais, 1991.

FUNDAÇÃO GETÚLIO VARGAS: http://fgvnoticias.fgv.br/pt-br: acesso fevereiro 2015.

GITMAN, Lawrence J. Princípios de Administração Financeira. $12^{\mathrm{a}}$ edição. São Paulo: Pearson, 2010.

GOLDMAN, Pedrinho. Viabilidade de Empreendimentos Imobiliários: Modelagem técnica, orçamento e riscos de incorporação. Editora Pini, 2015. 
IBGE: http://www.ibge.gov.br/home/, acesso fevereiro e abril 2015.

http://www.ibge.gov.br/home/estatistica/pesquisas/pesquisa_resultados. php?id_pesquisa $=40$

JUNQUEIRA, Messias. Justificação ao Anteprojeto do Decreto - Lei no 9.760/46.

KURESKI, R.; RODRIGUES, R. L.; MORETTO, A. C.; SESSO FILHO, U. A.; HARDT, L. P. A. O macrossetor da construção civil na economia brasileira em 2004. Ambiente Construído, 2008.

MINISTÉRIO DO PLANEJAMENTO: http://www.planejamento.gov.br/: acesso maio 2015.

PEREIRA, Caio Mário da Silva. Condomínio e Incorporações. Forense, 1998.

PROGRAMA DE ACELERAÇÃO DO CRESCIMENTO: http://www.pac.gov.br/: acesso maio 2015.

PROGRAMA NACIONAL DE HABITAÇÃO URBANA: http://www.pnhu.com.br/ http://www.pnhu.com.br/fgts-financiamento-com-recursos-do-fundo-degarantia-do-tempo-de-servico/: acesso abril 2015.

RIBEIRO, Luiz Cesar Queiroz. Dos cortiços aos condomínios fechados: as formas de produção de moradia na cidade do Rio de Janeiro. RJ: Civilização Brasileira, 1997.

ROSS, Stephen A; WESTERFIELD, Randolph W.; JORDAN, Bradford D.. Fundamentos de Administração Financeira. AMGH, 2013.

SAMANEZ, Carlos Patricio. Matemática Financeira - Aplicação à análise de investimentos. São Paulo: Prentice Hall, 2002.

SEDHAB,

http://www.sedhab.df.gov.br/mapas sicad/conferencias/programa minha casa minha vida.pdf: acesso em abril 2015.

SEBRAE: http://www.sebrae.com.br/sites/PortalSebrae/ufs/ri??codUf=20; acesso abril 2015.

http://intranet.df.sebrae.com.br/download/blog responde/S\%C3\%A9rie\%20Empreendime ntos\%20Coletivos/SEC sociedade de proposito especifico.pdf; acesso em maio 2015.

SECRETARIA DE ESTADO DE GESTÃO DO TERRITÓRIO E HABITAÇÃO: http://www.sedhab.df.gov.br/: acesso maio 2015.

SECRETARIA MUNICIPAL DE HABITAÇÃO: http://www.rio.ri.gov.br/web/sm: acesso abril 2015.

SINDUSCON: http://www.sinduscon-rio.com.br/; acesso fevereiro, abril e maio 2015.

TEIXEIRA, L. P.; CARVALHO, F. M. A. A construção civil como instrumento 
do desenvolvimento da economia brasileira. Revista Paranaense de Desenvolvimento, n. 109, p. 9-26, 2005.

VALOR: $\quad$ http://www.valor.com.br/brasil/3733244/fgv-brasil-precisa-de-r-76-bi-ao-anopara-zerar-deficit-habitacional: acesso em maio 2015. 
7 Anexo 1

Não há anexos. 